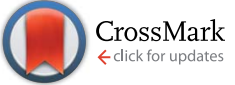

Cite this: RSC Adv., 2017, 7, 10947

\title{
Chemical approaches to inhibitors of isoprenoid biosynthesis: targeting farnesyl and geranylgeranyl pyrophosphate synthases
}

\begin{abstract}
Pedro Merino, ${ }^{\text {a }}$ Loredana Maiuolo, $^{\text {tb }}$ Ignacio Delso, ${ }^{\text {ac }}$ Vincenzo Algieri, ${ }^{\text {b }}$ Antonio De Nino $^{b}$ and Tomas Tejero ${ }^{a}$

Post-translational lipid modifications farnesylation and geranylgeranylation of proteins (protein prenylation) have been identified to mediate critical events in cancer, cardiovascular disorders, malaria and bone disorders like osteoporosis. To date eight compounds are commercialized for the treatment of bone disorders, and there are considerable efforts to develop selective small molecules that inhibit protein prenylation. This review summarizes the approaches currently employed to synthesize new inhibitors of isoprenoid biosynthesis. Bisphosphonates are mainly prepared through reaction of carboxylic acids with phosphorus reagents, Michael addition to tetraethylvinylidenebisphosphonate and alkylation of tetralkylmethyl bisphosphonate. Approaches to non-bisphosphonate derivatives include a variety of methodologies depending on the structure of the target compound.
\end{abstract}

Received 16th December 2016 Accepted 7th February 2017

DOI: 10.1039/c6ra28316k

rsc.li/rsc-advances

40.000 representatives have been found in all kingdoms of life. ${ }^{3}$ They participate in a great variety of basic biological functions in plants ${ }^{4,5}$ (e.g. growth regulation, pigments) and mammals ${ }^{6-8}$ (e.g. steroids metabolism, cellular signaling, antioxidants), and have been used in the food, pharmaceutical, chemical and biofuel industries., ${ }^{\mathbf{9} 10}$

Isoprenoids are biosynthesized ubiquitously in eubacteria,

${ }^{a}$ Departamento de Sintesis y Estructura de Biomoléculas, ISQCH, Universidad de Zaragoza-CSIC, 50009 Zaragoza, Aragón, Spain. E-mail: pmerino@unizar.es

${ }^{b}$ Dipartimento di Chimica, Università della Calabria, 87036 Rende, Italy

'Servicio de Resonancia Magnética Nuclear, CEQMA, Universidad de Zaragoza-CSIC, 50009 Zaragoza, Aragón, Spain archaebacteria and eukaryotes by the consecutive condensation of the five-carbon monomer isopentenyl diphosphate (IPP) to its isomer dimethylallyl pyrophosphate (DMAPP) (Fig. 1). ${ }^{\mathbf{1 1 , 1 2}}$ Whereas

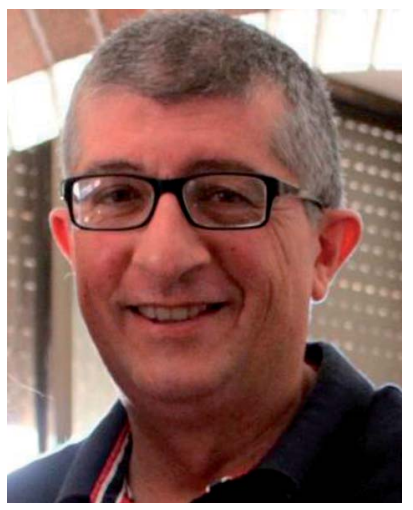

Pedro Merino (b. Zaragoza, Spain) received his $M . S c$. degree in Organic Chemistry (1986) at the University of Zaragoza. After Ph.D. studies (1989) he moved to Ferrara (Italy) as a post-doctoral associate with Professor Alessandro Dondoni (1989-1992). In 1992 he joined the University of Zaragoza as Assistant Professor. In 1993 he was promoted to Associate Professor and Senior Lecturer in 1994. In 2005 he won national habilitation as full professor in Organic Chemistry. In 2006 he won a Chair in Organic Chemistry at the University of Zaragoza. His research interests include chemical biology, organocatalysis and computational chemistry.

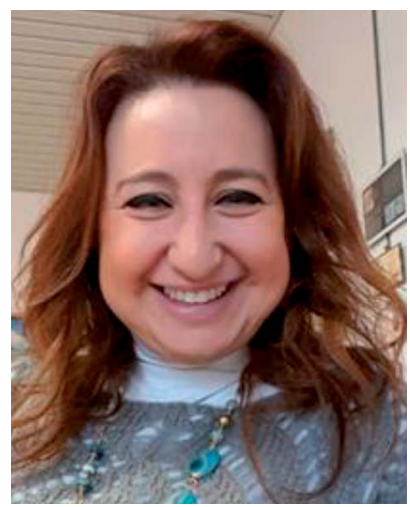

Loredana Maiuolo (b. Cosenza, Italy) graduated in Chemistry at the University of Calabria (1995) where received her Ph.D (1999). She carried out two postdoctoral positions in Organic Chemistry at the University of Calabria (1999-2004). In 2005 she won a permanent position as Researcher in Organic Chemistry at University of Calabria. In 2014 she spent six months at University of Zaragoza as visiting professor. Her main fields of research include: Asymmetric Synthesis of Biologically Active Molecules by 1,3-Dipolar Cycloaddition; Synthesis of Organic Compounds in non-conventional Solvents; Lewis Acids Catalysts and Organocatalysis; Synthesis of Deuterated Compounds as Standard in Food Chemistry. 
in mammals and yeast IPP is synthesized in the cytosol and endoplasmic reticulum from acetyl-CoA through mevalonic acid (mevalonate pathway), in higher plants and other microorganisms IPP is synthesized in the plastids by the condensation of pyruvate with glyceraldehyde-3-phosphate through 1-deoxyxylulose-5phosphate (DXP) - also called methylerythritol (MEP pathway). Two consecutive condensations of IPP and DMAPP catalyzed by farnesyl pyrophosphate synthase (FPPS) provide geranyl diphosphate (GPP) and farnesyl diphosphate (FPP). The former is the precursor of monoterpenes and the latter of sesquiterpenes, triterpenes and sterols (via squalene biosynthesis) as well as other important secondary metabolites like ubiquinones and dolichols. An additional condensation of FPP with IPP, catalyzed by the enzyme geranylgeranyl pyrophosphate synthase (GGPPS), furnishes geranylgeranyl pyrophosphate (GGPP) precursor of diand tetraterpenes and carotenoids (Fig. 1).

Given the importance of the metabolites accessible from isoprenoid biosynthesis, the enzymes involved in the process are excellent drug targets. ${ }^{\mathbf{1 3}, \mathbf{1 4}}$ The non-mevalonate pathway (MEP pathway) is not present in mammalian systems; consequently the enzymes involved in MEP pathway are attractive drug targets ${ }^{15}$ for the development of herbicides, antimicrobial drugs and fighting against pathogenic microorganisms like P. falciparum (malaria), ${ }^{\mathbf{1 6 , 1 7}}$ T. cruzi (Chagas disease) ${ }^{\mathbf{1 8 , 1 9}}$ and M. tuberculosis. ${ }^{20}$ Enzymes in the MEP pathway, IspG and IspH, are anti-infective drug targets $^{21}$ and HMG-CoA reductase involved in the synthesis of IPP is the primary target of hypocholesterolemic drug therapy. ${ }^{22}$

Protein prenylation, in particular farnesylation and geranylgeranylation, is one of the essential post-translational protein modification in the eukaryote. ${ }^{23}$ Therefore inhibition and/or modulation of the enzymes FPPS and GGPPS will affect not only to essential secondary metabolites derived from isoprenoid biosynthesis ${ }^{24}$ but also to the functionality of prenylated proteins. ${ }^{25}$ FPPS has been identified as a target for a series of drugs acting as anticancer, antimicrobial and antiparasitic

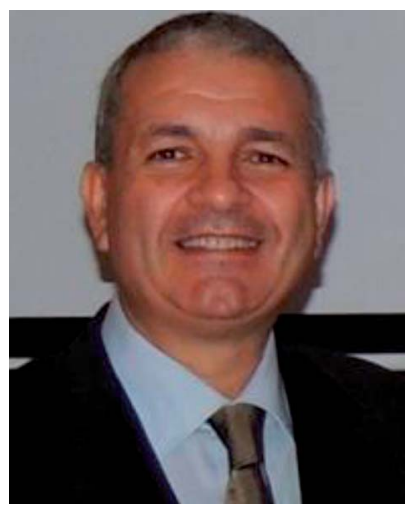

Antonio De Nino (b. Capistrano $(\mathrm{VV})$, Italy) received the degree in Chemistry at University of Calabria (1989). From 1993 to 2003, he was researcher in Organic Chemistry at the Chemistry Department of University of Calabria. Since 2003 he is Associate Professor of Organic Chemistry at the same University. His research activities are mainly devoted to study: Asymmetric Synthesis of Biologically Active Molecules by 1,3-Dipolar Cycloaddition; Synthesis of Organic Compounds in non-conventional Solvents; Lewis Acids Catalysts and Organocatalysis; Determination and Characterization of Microcomponents in Food and Natural Products; Reactivity of Enaminones Dianions with Electrophiles.

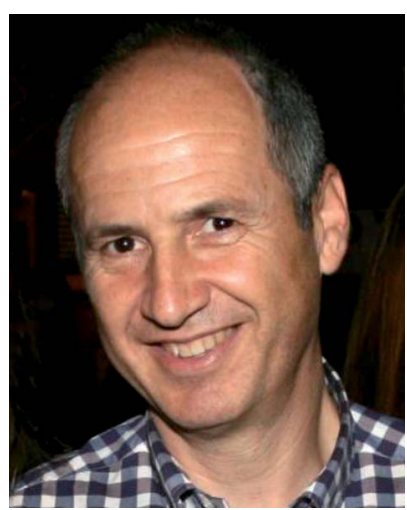

Tomas Tejero (b. Zaragoza, Spain) coursed Chemistry at the University of Zaragoza (1980) where he received his Ph.D. (1985). In 1984 he became Assistant Professor and in 1985 he spent a year in the University Pierre et Marie Curie (Paris) under the supervision of Prof. J. Normant. In 1986 he returned to Zaragoza and in 1987 he was promoted to Senior Lecturer. In 2012 he was appointed Full Professor in the Department of Organic Chemistry at the University of Zaragoza. He is particularly interested in enantioselective processes and in new spectroscopic techniques to the field of the Asymmetric Synthesis. 


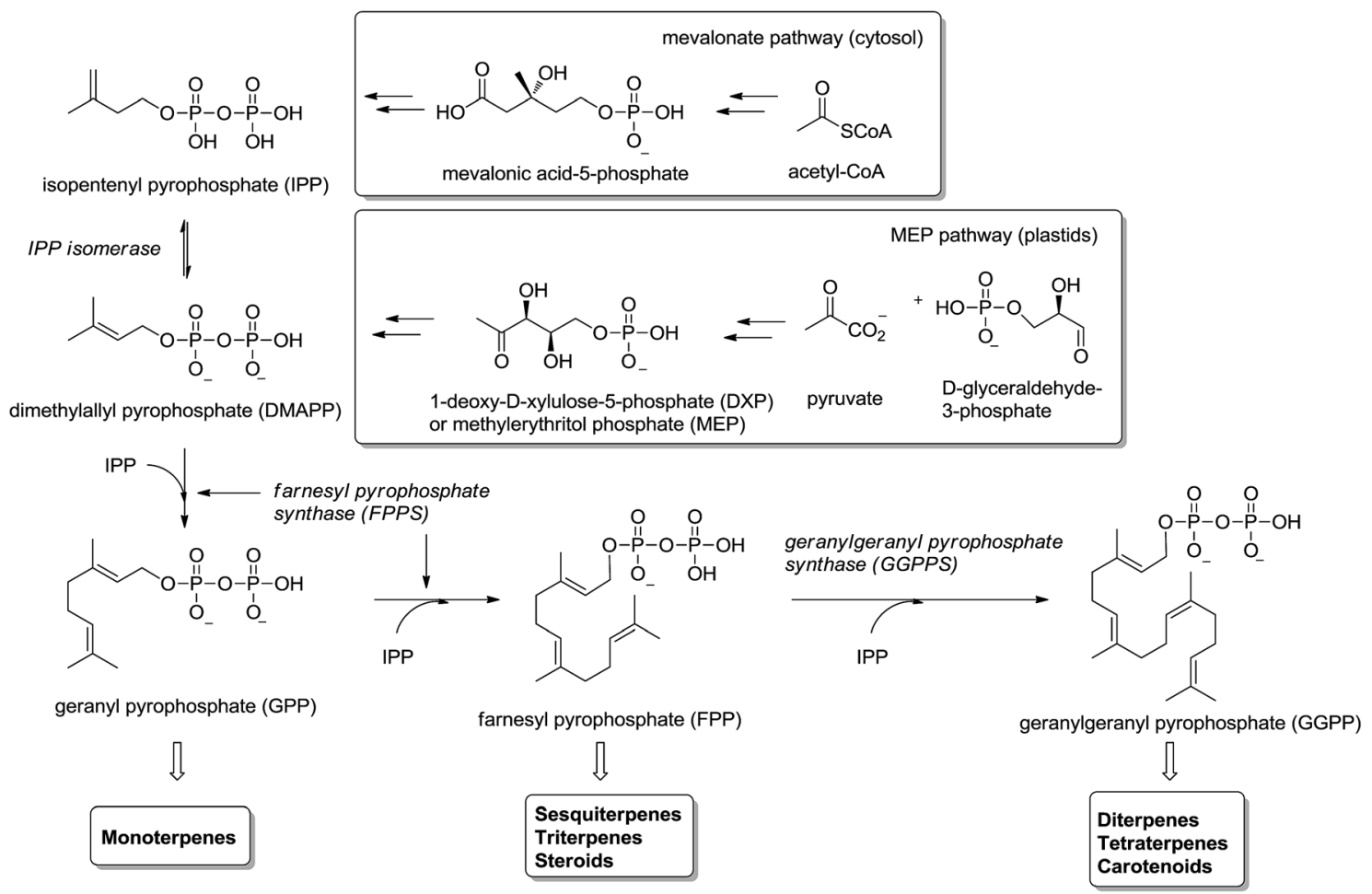

Fig. 1 Biosynthesis of isoprenoids. FPPS and GGPPS are essential enzymes.<smiles>O=P(O)(O)OP(=O)(O)O</smiles>

1, Pyrophosphate<smiles>CC(O)(P(=O)(O)O)P(=O)(O)O</smiles>

2, Etidronate (Mylan $^{\circledR}$, Didronel $^{\circledR}$ )<smiles>O=P(O)(O)C(Cl)(Cl)P(=O)(O)O</smiles>

3, Cloronate (Osphos ${ }^{\circledR}$ )<smiles>NCCCC(O)(P(=O)(O)O)P(=O)(O)O</smiles>

4, Alendronate (Fosamax ${ }^{\circledR}$ )<smiles>NCCC(O)(P(=O)(O)O)P(=O)(O)O</smiles>

5, Pamidronate (Padium ${ }^{\circledR}$ )<smiles>CCCCCN(C)CCC(O)(P(=O)(O)O)P(=O)(O)O</smiles>

6, Ibandronate (Boniva $^{\circledR}$, Bondronat $^{\circledR}$ )<smiles>O=P(O)(O)C(O)(Cc1cccnc1)P(=O)(O)O</smiles>

7, Risedronate

(Actonel $^{\circledR}{ }^{\text {, Risedol }}{ }^{\circledR}$, Risofos $^{\circledR}$ )<smiles>O=P(O)(O)C(O)(Cn1ccnc1)P(=O)(O)O</smiles>

8, Zoledronate (Zometa $^{\circledR}$, Aclasta $^{\circledR}$ )<smiles>O=P(O)(O)C(O)(Sc1ccc(Cl)cc1)P(=O)(O)O</smiles>

9, Tiludronate $\left(\right.$ Tildren ${ }^{\circledR}$ )

Fig. 2 FDA-approved bisphosphonates clinically used for the treatment of bone disorders. Compounds are presented in their protonated forms.

agents. $^{26}$ In particular, human FPPS is a drug target for cancer, ${ }^{27,28}$ osteoporosis and related diseases, ${ }^{29-31}$ Paget's disease, ${ }^{32,33}$ metastatic diseases, ${ }^{34}$ and cardiovascular disorders. ${ }^{35}$ Inhibition of human GGPPS has been reported as a new route to bone antiresorption ${ }^{36}$ and the same enzyme from Plasmodium has been identified as a target against malaria. ${ }^{37}$ The multiple sequence alignment of FPPS and GGPPS found in different organisms ${ }^{38,39}$ makes that the same potential inhibitor should be tested against both enzymes from diverse biological sources. The main group of inhibitors is constituted by bisphosphonates (BPs), ${ }^{40}$ structural analogues of DMAPP considered chemically stable analogues of inorganic pyrophosphate. Bisphosphonates, known from more than 40 years $^{\mathbf{4 1}}$ are being used clinically in the treatment of osteoporosis and malignant bone diseases (Fig. 2). ${ }^{42}$

Simple bisphosphonates correspond to analogues of pyrophosphate 1 with therapeutic properties in which the bridging oxygen atom has been replaced by a methylene group that can incorporate non-nitrogenated substituents. Typical examples are etidronate $\mathbf{2}$ and cloronate $\mathbf{3}$ and their mechanism of action consists of being incorporated to non-hydrolyzable analogues of ATP, inducing osteoclast apoptosis. ${ }^{43}$

On the other hand, nitrogen-containing bisphosphonates (e.g. alendronate $\mathbf{4}$, pamidronate $\mathbf{5}$, ibandronate $\mathbf{6}$, risedronate 7, zoledronate 8) showed to be more than 10000 times more active than non-nitrogenated derivatives. These analogues have 
a diverse mechanism of action causing (i) disruption of normal function of essential signaling proteins ${ }^{\mathbf{4 4}}$ and (ii) accumulation of IPP which is incorporated into a toxic nucleotide metabolite. ${ }^{45}$ More recently, a variety of non-nitrogenated bisphosphonates like tiludronate $\mathbf{9}$ and others bearing arylsulfonium and phosphonium groups showed cytotoxicity against cancer, inhibition of TpFPPS and stimulation of T-cells in the human immune system revealing that the presence of a nitrogen atom is not strictly necessary. In addition to bisphosphonates, other inhibitors including quinoline and salicylic acid derivatives, have been reported. These non-bisphosphonate inhibitors bind to an allosteric site on FPPS identified by X-ray crystallography. ${ }^{\mathbf{4 6}}$

The goal of this review is to highlight synthetic methodologies directed to the preparation of FPPS and GPPS inhibitors. Several reviews have been reported elsewhere on the design of inhibitors of isoprenoid synthase enzymes ${ }^{\mathbf{1 3 , 1 4 , 4 7}}$ and their mechanism of action. ${ }^{45,48-51}$ The reader is directed to consult those reviews for details on therapeutic effects. Since the main focus of this survey is discussion on chemical approaches, references to biological activities of the inhibitors is only shortly reviewed here. No patents are considered in this review since they have been recently surveyed. ${ }^{52,53}$ The review is organized on the basis of the structure of the inhibitor, i.e. bisphosphonates and non-bisphosphonates and then by the synthetic methodologies employed for their synthesis.

\section{Bisphosphonates}

\section{Reaction of carboxylic acids with phosphorous reagents}

The most general and attractive approach for preparing 1,1bisphosphonates is the reaction of a carboxylic acid, easily accessible by conventional methods, with an inexpensive phosphorous reagent like phosphorous trichloride. Due to high therapeutic interest of 1,1-bisphosphonates, the first reports regarding their synthesis were published as patents and no clear experimental details were given, the reaction being difficult to scale up and lacking of reproducibility. Indeed, no mechanism of the reaction had been determined and a great variability was observed in reactants ratio, temperature, reaction time and work-up. In 1995, Kieczykowski and Jobson, from Merck and Co., Inc., reported a general procedure for reacting a carboxylic acid with phosphorous acid and phosphorous trichloride in the presence of methanesulfonic acid (Scheme 1). ${ }^{54}$

Since then, this method has been the most widely used for the synthesis of 1-hydroxy-1,1-bisphosphonates although in some particular case it has been reported contamination of the product with the methanesulfonate salt, that can be avoided by performing the reaction without solvent. ${ }^{55}$ The procedure is amenable of being used with several substrates including those bearing an amino functionality. ${ }^{36,56}$ For instance, alendronate 4 and pamidronate $\mathbf{5}$, have been prepared by this route ${ }^{57}$ and served as precursors of substituted analogues like compounds 13 (Scheme 2). ${ }^{\mathbf{5 8 , 5 9}}$ Similarly, conjugates 14 have been prepared by condensation of $\mathbf{5}$ with the corresponding carboxylic acid. ${ }^{60}$ Other conjugates include incorporation to nucleosides ${ }^{61}$ and oligonucleotides. ${ }^{62}$ Pamidronate 5 prepared by this route has

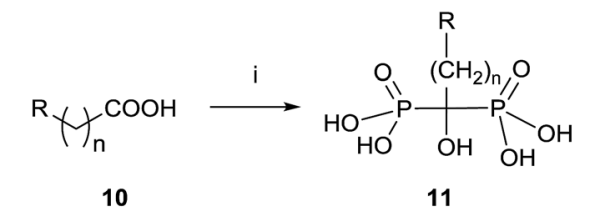

\begin{tabular}{lcc}
$\mathrm{R}$ & $\mathrm{n}$ yield (\%) \\
\hline $\mathrm{NH}_{2}$ & 2 & 57 \\
$\mathrm{NH}_{2}$ & 3 & 89 \\
$\mathrm{NH}_{2}$ & 4 & 78 \\
$\mathrm{NH}_{2}$ & 5 & 89 \\
$\mathrm{Me}$ & 10 & 95 \\
$\mathrm{Cl}$ & 1 & 31
\end{tabular}

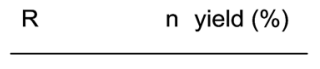

3-imidazoyl 138

3-pyridyl $\quad 1 \quad 26$

$4-\mathrm{H}_{2} \mathrm{NC}_{6} \mathrm{H}_{4} \quad 3 \quad 30$

Scheme 1 Reagents and conditions: (i) $\mathrm{H}_{3} \mathrm{PO}_{3}$ (1 equiv.), $\mathrm{MeSO}_{3} \mathrm{H}$ (1 equiv.), $\mathrm{PCl}_{3}$ (2 equiv.), $65^{\circ} \mathrm{C}, 16-20 \mathrm{~h}$; then $\mathrm{H}_{2} \mathrm{O}$, reflux; then $\mathrm{pH}=4$, $50 \% \mathrm{NaOH}$.

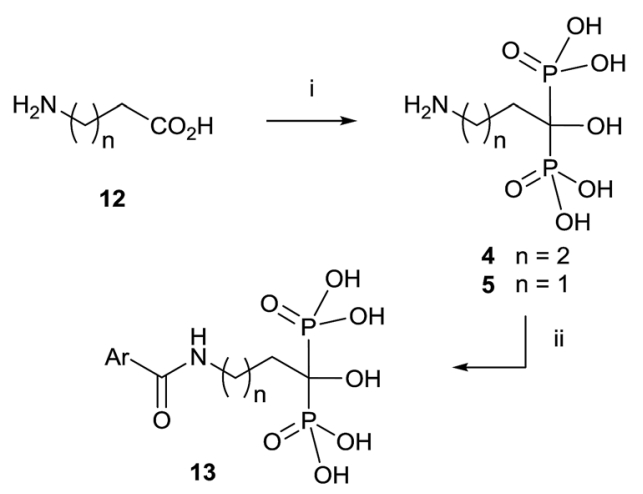

Ar: Ph, 2,3-diOMeC $\mathrm{H}_{3}, 3,4-\mathrm{CH}_{2} \mathrm{O}_{2} \mathrm{C}_{6} \mathrm{H}_{3}, 4-\mathrm{MeC}_{6} \mathrm{H}_{4}$, 3$\mathrm{MeOC}_{6} \mathrm{H}_{4}, 2-\mathrm{MeC}_{6} \mathrm{H}_{4}, 4-\mathrm{MeOC}_{6} \mathrm{H}_{4}$

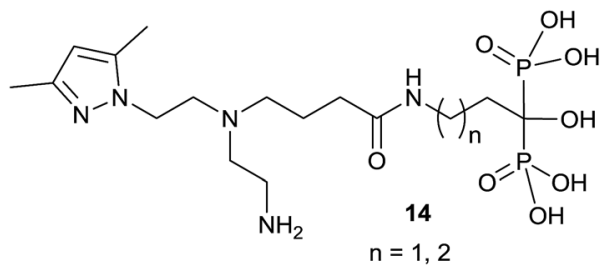

Scheme 2 Reagents and conditions: (i) $\mathrm{H}_{3} \mathrm{PO}_{3}, \mathrm{PCl}_{3}$. (ii) $\mathrm{ArCOCl}, \mathrm{NaOH}$.

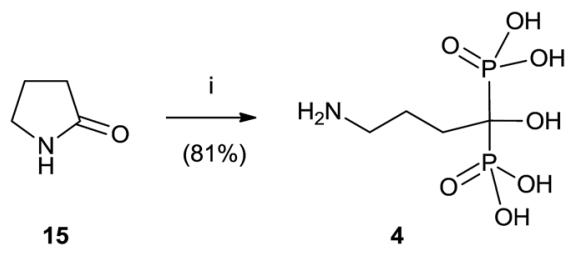

Scheme 3 Reagents and conditions: (i) $\mathrm{H}_{3} \mathrm{PO}_{3}, \mathrm{PCl}_{3}$. (ii) $\mathrm{ArCOCl}, \mathrm{NaOH}$.

been further employed for the synthesis of ${ }^{211}$ At-labeled amidobisphosphonates. ${ }^{63}$

Alendronate 4 can also be obtained in a straightforward manner from pyrrolidone (Scheme 3). ${ }^{64}$ Hydrolysis of 15 in 
aqueous methanesulfonic acid followed by reaction with phosphorous trichloride and hydrolysis with water furnished compound 4.

Good yields in the synthesis of heterocyclic (risedronate 7, zoledronate 8) and aminoalkyl bisphosphonates were obtained in just 20 min using microwaves and sulpholene as a solvent in the first stage of the reaction (Scheme 4).${ }^{65} \mathrm{~A}$ chiral analogue of risedronate 7 was prepared starting from 3-benzyloxybenzaldehyde 18 which was transformed into carboxylic acid 22. Reaction of 22 with phosphorous acid and phosphorous chloride afforded analogue 23 (Scheme 5). ${ }^{66}$ The complex<smiles>[R]CC(=O)O</smiles>

16

$4,5,7,8,17$

\begin{tabular}{clc} 
compound & $\mathrm{R}$ & yield (\%) \\
\hline $\mathbf{8}$ & 3-imidazoyl & 74 \\
$\mathbf{7}$ & 3-pyridyl & 70 \\
$\mathbf{5}$ & aminomethyl & 64 \\
$\mathbf{4}$ & aminoethyl & 41 \\
$\mathbf{1 7}$ & aminobutyl & 53
\end{tabular}

Scheme 4 Reagents and conditions: (i) $\mathrm{H}_{3} \mathrm{PO}_{3}$ (3 equiv.), $\mathrm{PCl}_{3}$ (4 equiv.), sulpholene, $65^{\circ} \mathrm{C}, 3-7$ min, $\mathrm{MWI} 200-400 \mathrm{~W}$ max.; then $\mathrm{H}_{2} \mathrm{O}$, MWI, 450-500 W max., $10 \mathrm{~min}, 150^{\circ} \mathrm{C}$.<smiles>CCCC1C=Cc2ccncc21</smiles><smiles>Nc1c(O)ccc2ccncc12</smiles>
19<smiles>[13CH3][13CH3]</smiles><smiles>CC(C)(C)CCCCCCCCCCC(=O)O</smiles>

22

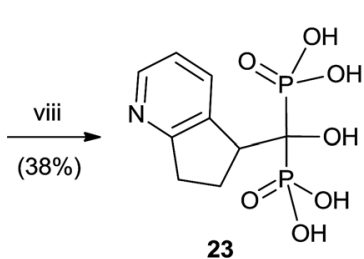

23<smiles>N#Cc1c(O)ccc2ccncc12</smiles>

20

Scheme 5 Reagents and conditions: (i) aminoacetaldehyde dimethylacetal, toluene, $6 \mathrm{~h}, 110{ }^{\circ} \mathrm{C}$; then TFA, $\mathrm{BF}_{3} \cdot \mathrm{Et}_{2} \mathrm{O},<10{ }^{\circ} \mathrm{C}, 4$ days; then $\mathrm{Et}_{2} \mathrm{O}, \mathrm{NH}_{4} \mathrm{OH}$ to $\mathrm{pH}$ 9. (ii) Sulfolane, nitronium tetrafluoroborate, rt, $6 \mathrm{~h}$. (iii) $10 \% \mathrm{Pd} / \mathrm{C}, \mathrm{H}_{2}, \mathrm{EtOH}$. (iv) $\mathrm{MeOH} \cdot \mathrm{HCl}, t-\mathrm{BuONO} 0{ }^{\circ} \mathrm{C}$ to rt, $4 \mathrm{~h}$. (v) $\mathrm{NaHCO}_{3}, \mathrm{MeOH}$, hv, $0{ }^{\circ} \mathrm{C}, 3$ h. (vi) $10 \% \mathrm{Pd} / \mathrm{C}, \mathrm{MeOH}, \mathrm{rt}, 5$ h. (vii) $\mathrm{NaOH}, 58^{\circ} \mathrm{C}, 4$ h. (viii) $\mathrm{H}_{3} \mathrm{PO}_{3}, \mathrm{PCl}_{3}$, toluene, $110{ }^{\circ} \mathrm{C}, 4 \mathrm{~h}$; then $\mathrm{HCl}$, $100{ }^{\circ} \mathrm{C}$, overnight. formed from $H s$ FPPS and racemic 23 revealed that only $R$ isomer was present in the active site revealing a high enantiospecificity of the enzyme.

Oldfield and co-workers have demonstrated that the methodology originally reported by Kieczykowski and Jobson ${ }^{54}$ allows preparing a huge number of different compounds, including aromatic, aliphatic, sulfur-containing and nitrogen-containing heterocyclic derivatives. ${ }^{67-71}$ The exact protocol involved a hydrolysis, after the reaction of the carboxylic acid with phosphorous acid and phosphorous trichloride, and $\mathrm{pH}$ adjustment to 4.3 with a $50 \% \mathrm{NaOH}$ solution, followed by recrystallization from water. ${ }^{67}$

A modified procedure was reported by the same group for the synthesis of pyridinium-1-yl bisphosphonates 27. The corresponding carboxylic acids 26 prepared through a cross-coupling reaction followed by $N$-alkylation with bromoacetic acid, were made to react with 5 equiv. of phosphorous acid and 5 equiv. of phosphorous trichloride in toluene without methanesulphonic acid. After treating the mixture with $6 \mathrm{~N} \mathrm{HCl}$ and reflux for $1 \mathrm{~h}$, addition of 2-propanol precipitated the 1,1-bisphosphonates which were further recrystallized from ethanol/water (Scheme 6). ${ }^{72}$

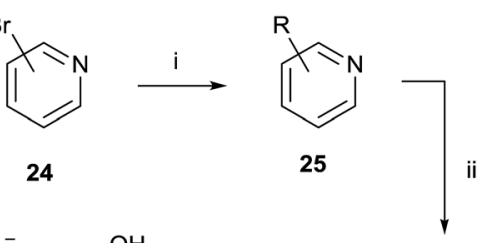<smiles>[R]c1cccc(-[n+]2cccc([R])c2)c1</smiles><smiles>[R]c1ccc[n+](CC(O)(P(=O)(O)O)P(=O)(O)O)c1</smiles>

$$
\begin{array}{ll}
\mathrm{R}=\mathrm{H} & (68 \%) \\
\mathrm{R}=\mathrm{Me} & (57 \%) \\
\mathrm{R}=\mathrm{Et} & (60 \%) \\
\mathrm{R}=\mathrm{nPr} & (51 \%) \\
\mathrm{R}=\mathrm{MeO} & (72 \%) \\
\mathrm{R}=\mathrm{F} & (46 \%) \\
\mathrm{R}=\mathrm{Ph} & (65 \%) \\
\mathrm{R}=4-\mathrm{OHC}_{6} \mathrm{H}_{4} & (40 \%) \\
\mathrm{R}=3-\mathrm{PhC}_{6} \mathrm{H}_{4} & (56 \%) \\
\mathrm{R}=\mathrm{C}_{6} \mathrm{H}_{5} \mathrm{CH}_{2} & (60 \%) \\
\mathrm{R}=3-\mathrm{MeC}_{6} \mathrm{H}_{4} \mathrm{CH}_{2} & (70 \%)
\end{array}
$$<smiles>O=P(O)(O)C(O)(C[n+]1ccc2ccccc2c1)P(=O)(O)O</smiles>

$(47 \%)$<smiles>O=P(O)(O)C(O)(C[n+]1cccc2cc(Cl)ccc21)P(=O)(O)O</smiles>

$(10 \%)$
Scheme 6 Reagents and conditions: (i) $\mathrm{R}-\mathrm{B}(\mathrm{OH})_{2}, \mathrm{Pd}\left(\mathrm{PPh}_{3}\right)_{4}, \mathrm{~K}_{2} \mathrm{CO}_{3}$, toluene, $\mathrm{H}_{2} \mathrm{O}, 10 \mathrm{~h}$, reflux. (ii) $\mathrm{BrCH}_{2} \mathrm{CO}_{2} \mathrm{H}$, pyridine, EtOAc, 2 days, rt. (iii) $\mathrm{H}_{3} \mathrm{PO}_{3}$ (5 equiv.), $\mathrm{PCl}_{3}$ (5 equiv.), toluene, $80{ }^{\circ} \mathrm{C}, 5 \mathrm{~h}$; then $6 \mathrm{~N} \mathrm{HCl}$, $1 \mathrm{~h}$, reflux. 
This protocol was also applied to the synthesis of aliphatic and aromatic derivatives with or without heteroatoms, demonstrating a great tolerance with respect to the chemical nature of the substrates. ${ }^{73}$ Labelled pamidronic acid- ${ }^{13} \mathrm{C}_{3},{ }^{15} \mathrm{~N}$, alendronic acid- ${ }^{15} \mathrm{~N}$, zoledronic acid $-{ }^{15} \mathrm{~N}_{2}$ and risedronic acid- ${ }^{15} \mathrm{~N}$ were also synthesized by using those conditions. ${ }^{74}$ Pyridinium fluorescently-labeled conjugates of risedronate 7 were synthesized using an epoxide linker which was bonded to the pyridyl nitrogen. The conjugates were used for fluorescence imaging of Bacillus subtilis. ${ }^{75}$

Despite this synthetic activity that demonstrate the utility of the carboxylic acid-approach, various inconsistent procedures appeared in patents concerning the synthesis of the most clinically used zoledronic and risedronic acids which has been the matter of some controversy regarding the reagents and the ratio between them to be used. Dedicated reviews have been reported with the aim of clarifying the situation including the mechanism $^{76}$ of the reaction. ${ }^{77,78}$ In 2011 , Keglevich and co-workers finally established that the best conditions correspond to the use phosphorous trichloride in $1: 3.2$ molar ratio in methanesulfonic acid. ${ }^{79}$ Alternatively, it has also been reported the use of benzenesulfonic acid as a solvent. ${ }^{80}$ When the reaction is carried out in the presence of paraformaldehyde, bisphosphonic acids can be obtained without the addition of water, ${ }^{\mathbf{1 1}}$ the use of microwaves enhancing the yield of the reaction. ${ }^{82,83}$ By using their conditions, Keglevich and co-workers reported the synthesis of etidronate $\mathbf{2}$, alendronate $\mathbf{4}$, pamidronate $\mathbf{5}$, ibandronate $\mathbf{6}$, risedronate and 7 zoledronate acid $\mathbf{8}$ (Scheme 7). ${ }^{84}$ The exact treatment of the reaction comprised the use of only 3.2 eq. of phosphorous trichloride as the P-reagent in

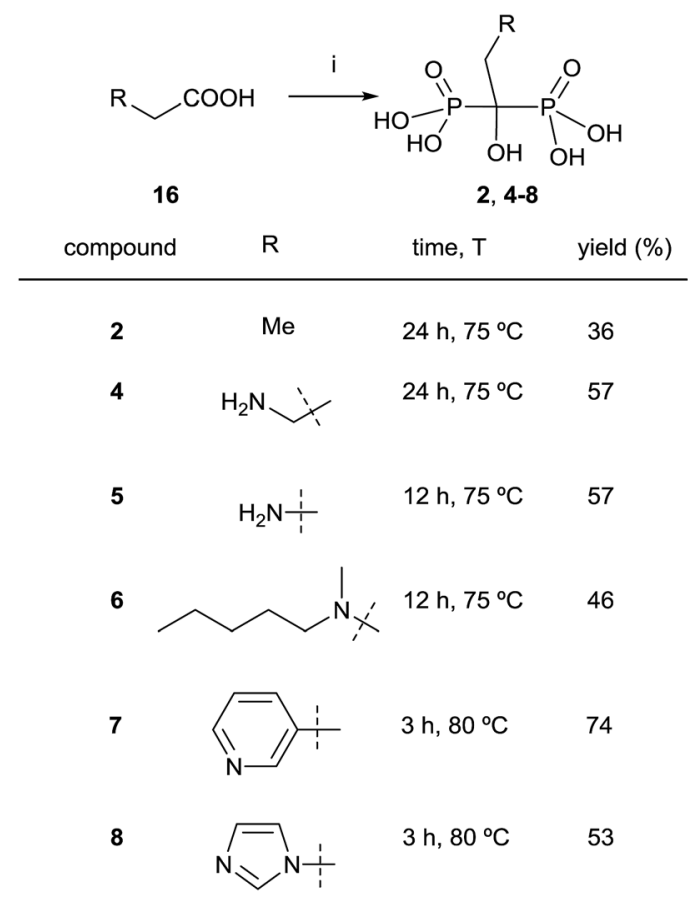

Scheme 7 Reagents and conditions: (i) $\mathrm{PCl}_{3}$ (3.2 equiv.), $\mathrm{MeSO}_{3} \mathrm{H}$, see scheme for time and temperature; then $\mathrm{H}_{2} \mathrm{O}, 4-5 \mathrm{~h}, 105^{\circ} \mathrm{C}$; then $50 \%$ aq. $\mathrm{NaOH}$ to $\mathrm{pH}=1.8-2.0$. methanesulfonic acid as a solvent (without addition of phosphorous acid). In fact, it had been reported the use of that solvent for large-scale preparations. ${ }^{\mathbf{8 5}}$ Time and temperature were adjusted in each case for the first stage of the reaction at which time water was added and the resulting mixture was heated at $105^{\circ} \mathrm{C}$ for $5 \mathrm{~h}$. This was followed by hydrolysis with 10 $\mathrm{N} \mathrm{NaOH}$ and $\mathrm{pH}$ adjustment to 1.8-2.0. Notably, the different dronic acids prepared required different purification conditions. Whereas 2, 4 and $\mathbf{6}$ were purified by direct precipitation in water, 5 was purified by digestion in $\mathrm{MeOH}$ followed by precipitation in water, 7 was purified by washing with water and 8 was purified by recrystallization from $\mathrm{HCl}$. Further work in different solvents ${ }^{86}$ allowed establishing the best conditions for doing the reaction. ${ }^{83}$

A variation using phosphorous oxychloride has allowed a one-pot multigram synthesis of zoledronic acid 8 in high yield (Scheme 8). ${ }^{87}$ The procedure has been carried out with $200 \mathrm{~g}$ of compound 28, easy accessible from imidazole. ${ }^{88}$ The use of phosphorous oxychloride has also been successfully used for the synthesis of aledronate 4 and risedronic acid $7 .{ }^{89}$ On the other hand, phosphorous trichloride was the preferred reagent in the synthesis of benzidronate. ${ }^{90}$

Nitriles 29 can also be used as an alternative to carboxylic acids and the reaction can be performed under similar

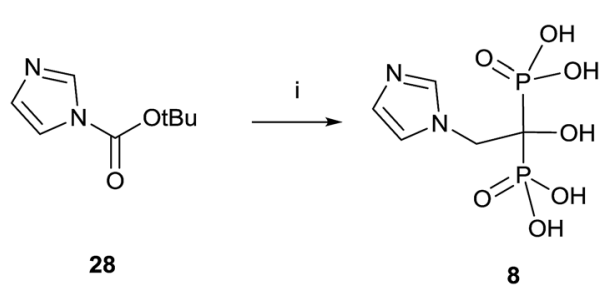

Scheme 8 Reagents and conditions: (i) $\mathrm{H}_{3} \mathrm{PO}_{3}, 4$-chlorobenzene, $25^{\circ} \mathrm{C}, 15 \mathrm{~min}$; then $\mathrm{CH}_{3} \mathrm{SO}_{3} \mathrm{H}, 30 \mathrm{~min}, 70{ }^{\circ} \mathrm{C}$; then $\mathrm{POCl}_{3}, 95^{\circ} \mathrm{C}, 24 \mathrm{~h}$; then $\mathrm{H}_{2} \mathrm{O}, 6 \mathrm{~h}, 90{ }^{\circ} \mathrm{C}$; then $30 \% \mathrm{NaOH}, \mathrm{pH}=4.1$.
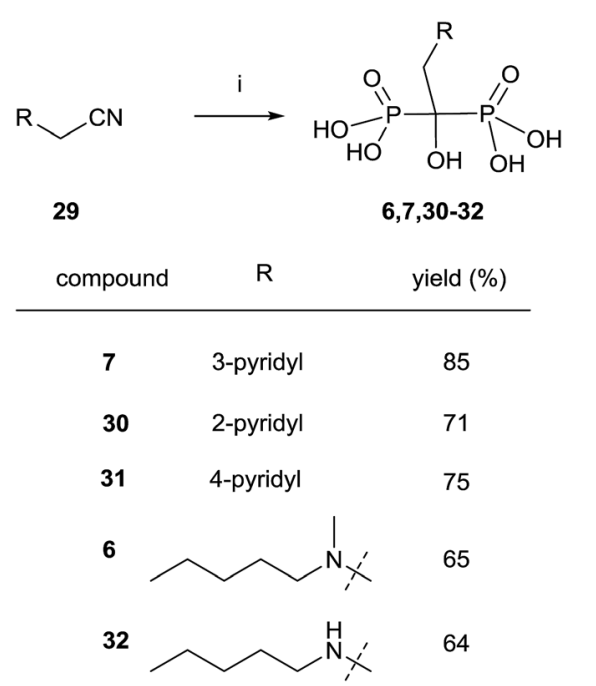

Scheme 9 Reagents and conditions: (i) $\mathrm{CH}_{3} \mathrm{SO}_{3} \mathrm{H}, 8 \mathrm{~h}, 100{ }^{\circ} \mathrm{C}$; then $\mathrm{PCl}_{3}, 70{ }^{\circ} \mathrm{C}, 5 \mathrm{~h}$; then $\mathrm{H}_{2} \mathrm{O}, 15 \mathrm{~h}, 98^{\circ} \mathrm{C}$. 
conditions but without the presence of phosphorous acid (Scheme 9). ${ }^{91}$ Risedronate 7 prepared by this route was further labeled with ${ }^{99} \mathrm{Tc}$ by forming the corresponding complex. ${ }^{92}$

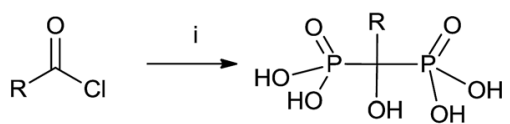

33

34

\begin{tabular}{lll}
$\mathrm{R}$ & solvent & $\mathrm{T}\left({ }^{\circ} \mathrm{C}\right) \quad$ yield $(\%)$ \\
\hline
\end{tabular}

$\begin{array}{lccc}\mathrm{Me} & \text { none } & 25 & 98 \\ \mathrm{C}_{5} \mathrm{H}_{11} & \text { none } & 25 & 97 \\ \mathrm{C}_{11} \mathrm{H}_{23} & \text { none } & 25 & 97 \\ \mathrm{C}_{6} \mathrm{H}_{5} \mathrm{CH}_{2} & \text { none } & 25 & 90 \\ \mathrm{C}_{6} \mathrm{H}_{5} & \text { none } & 25 & 91 \\ 4-\mathrm{MeOC}_{6} \mathrm{H}_{4} & \text { THF } & 25 & 90 \\ 4-\mathrm{NO}_{2} \mathrm{C}_{6} \mathrm{H}_{4} & \text { THF } & -70 & 85 \\ \text { 3-pyridyl } & \text { THF } & 25 & 61\end{array}$<smiles>C=C(C)C(=O)OCCOCC(O)(P(=O)(O)O)P(=O)(O)OC</smiles>

$36 n=8$

Scheme 10 Reagents and conditions: (i) $\mathrm{P}\left(\mathrm{OSiMe}_{3}\right)_{3}, \mathrm{O}^{\circ} \mathrm{C}$ then rt; then $\mathrm{MeOH}, 1 \mathrm{~h}, 25^{\circ} \mathrm{C}$.

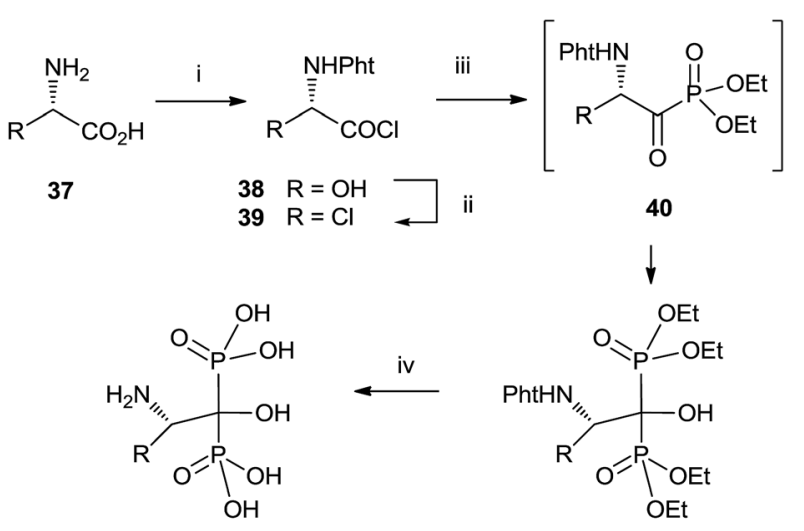

42

41

yield $(\%)$

\begin{tabular}{lllll} 
amino acid $\mathbf{3 7}$ & $\mathbf{3 8}$ & $\mathbf{3 9}$ & $\mathbf{4 1}$ & $\mathbf{4 2}$ \\
\hline phenylalanine & 88 & 88 & 30 & 50 \\
leucine & 81 & 90 & 25 & 90 \\
tryptophan & 95 & 93 & 50 & 88 \\
methionine & 92 & 85 & 44 & 95 \\
aspartic & 55 & 88 & 18 & 40 \\
glutamic & 83 & 89 & 48 & 99 \\
lysine & 80 & 80 & 18 & 90 \\
ornithine & 26 & 92 & 15 & 82 \\
valine & 81 & 85 & 18 & 90
\end{tabular}

Scheme 11 Reagents and conditions: (i) $\mathrm{N}$-(ethoxycarbonyl)phthalimide, $\mathrm{NaHCO}_{3}, \mathrm{O}^{\circ} \mathrm{C}, 5 \mathrm{~min}$. (ii) $\mathrm{SOCl}_{2}, \mathrm{CH}_{2} \mathrm{Cl}_{2}, 5 \mathrm{~h}$, reflux. (iii) Triethyl phosphite, toluene, $1 \mathrm{~h}, 0{ }^{\circ} \mathrm{C}$; then diethylphosphite, $\mathrm{Et}_{3} \mathrm{~N}, 1-3 \mathrm{~h}, \mathrm{O}-$ $5{ }^{\circ} \mathrm{C}$. (iv) $6 \mathrm{~N} \mathrm{HCl}$, reflux, overnight; then $5 \mathrm{~N} \mathrm{NaOH}, \mathrm{pH}=4.4$.

\section{Reaction of acylphosphonates with dialkyl phosphites}

In some instances, the direct reaction between a carboxylic acid and phosphorus trichloride takes place with low yields or fails completely as in the case of sterically hindered $\alpha$-aminoacids. A discussion comparing this route with that developed at the Merck company has been reported. ${ }^{93}$ An alternative is the use of the acyl chloride as starting material. The Arbuzov-type reaction $^{94}$ with a di-, trialkyl phosphite provides an $\alpha$-ketophosphonate (acylphosphonates) capable of reacting with another molecule of di-, trialkyl phosphite to give the corresponding 1hydroxy-1,1-bisphosphonate. The first report on this approach
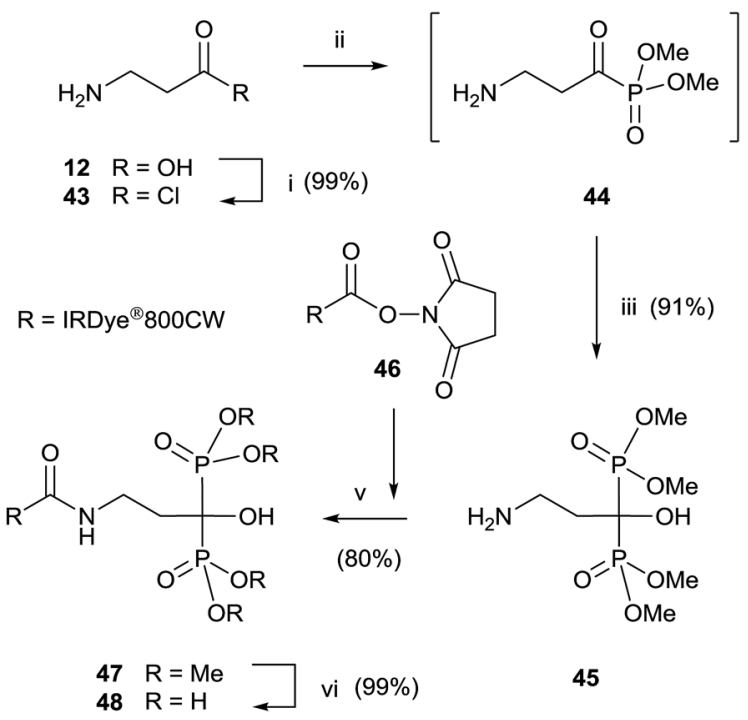

Scheme 12 Reagents and conditions: (i) $\mathrm{SOCl}_{2}, \mathrm{CH}_{2} \mathrm{Cl}_{2}, 1 \mathrm{~h}$, reflux. (ii) Trimethyl phosphite, toluene, $30 \mathrm{~min}, 0{ }^{\circ} \mathrm{C}$. (iii) Dimethylphosphite, $\mathrm{Et}_{3} \mathrm{~N}, 30 \mathrm{~min}, 0-5{ }^{\circ} \mathrm{C}$. (iv) DMSO, $\mathrm{N}$-methylmorpholine, $4 \mathrm{~h}, \mathrm{rt}$. (v) $\mathrm{Me}_{3} \mathrm{SiBr}, 18 \mathrm{~h}$, rt; then $4: 1 \mathrm{MeOH}-\mathrm{H}_{2} \mathrm{O}, 30 \mathrm{~min}$, rt

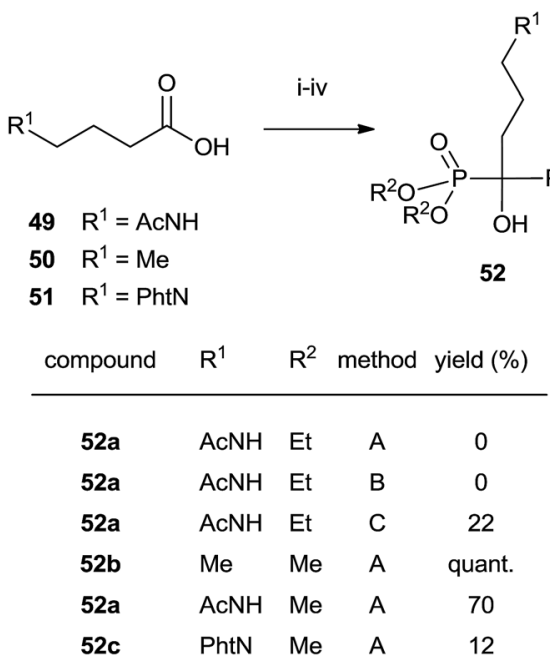

Scheme 13 Reagents and conditions: (i) $(\mathrm{COCl})_{2}, \mathrm{CH}_{2} \mathrm{Cl}_{2}, \mathrm{DMF}$ (cat.), $3 \mathrm{~h}$, rt. (ii) $\left(\mathrm{R}^{2} \mathrm{O}\right)_{3} \mathrm{P}, 1 \mathrm{~h}$, rt. (iii) $\left(\mathrm{R}^{2} \mathrm{O}\right)_{3} \mathrm{P}, \mathrm{TMSBr}, 1 \mathrm{~h}$, rt. (iv) Method A: aq. $6 \mathrm{M} \mathrm{HCl}, 17 \mathrm{~h}$, reflux; method $\mathrm{B}: \mathrm{MeSO}_{3} \mathrm{H}, 17 \mathrm{~h}$, reflux; method $\mathrm{C}: 48 \%$ $\mathrm{HBr}, 17 \mathrm{~h}$, reflux. 
described the use of tris(trimethylsilyl)phosphite as the only phosphorylating reagent (Scheme 10). ${ }^{95}$ The reaction proceeds under mild conditions rendering the process compatible with labile substrates ${ }^{96}$ including bile acids. ${ }^{97}$ Acrylic ester bisphosphonates 35,36 with numerous potential applications in biomedicine are also accessible through this approach. ${ }^{98}$

The direct use of trialkyl phosphites is also possible. A series of $\alpha$-amino acid derived bisphosphonates 42 has been prepared in good yield by using as starting materials $\mathrm{N}$-phthalimidoprotected amino acids and using sequentially tri- and diethyl phosphite as P-reagents (Scheme 11). ${ }^{99}$ Although the addition of<smiles></smiles>

53

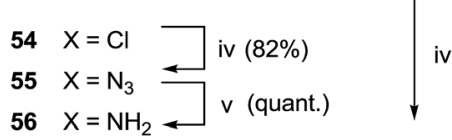<smiles>[R]C(=O)NCCCC([R])(P(=O)(O)O)P(=O)(O)O</smiles>
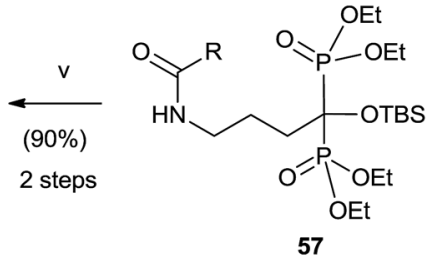

$58=T B S$
59 $\begin{array}{ll}\mathrm{R}=\mathrm{H} & \square \text { vi }(93 \%)\end{array}$

Scheme 14 Reagents and conditions: (i) $\mathrm{P}(\mathrm{OEt})_{3}, \mathrm{O}^{\circ} \mathrm{C}$. (ii) $\mathrm{HOP}(\mathrm{OEt})_{2}$ DMAP, $\mathrm{CH}_{2} \mathrm{Cl}_{2}$, room temp, 1 h. (iii) TBSCl, 15 h. (iv) $\mathrm{NaN}_{3}, \mathrm{DMF}, 75^{\circ} \mathrm{C}$, 2 h. (v) $\mathrm{Pd}-\mathrm{C}, 50$ psi of $\mathrm{H}_{2}, \mathrm{AcOEt}, 15$ h. (vi) $\mathrm{RCOCl}, \mathrm{Et}_{3} \mathrm{~N}, \mathrm{CH}_{2} \mathrm{Cl}_{2}$ or $\mathrm{RCO}_{2} \mathrm{H}$, EDC, DIPEA, MeCN. (v) TMSI, MeCN and then MeOH. (vi) TBAF, THF.

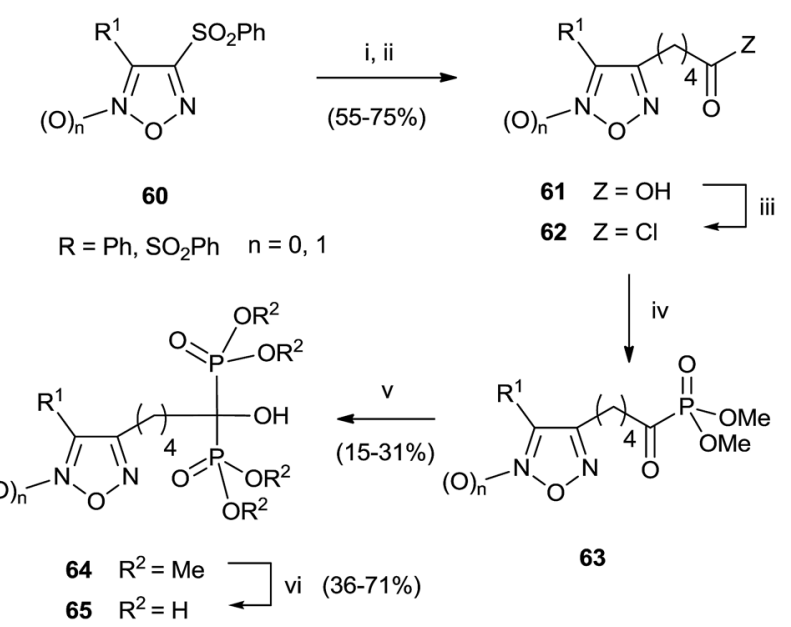

Scheme 15 Reagents and conditions: (i) 1,5-pentanediol, $\mathrm{NaOH} 50 \%$ $\mathrm{W} / \mathrm{w}$, THF. (ii) Jones reagent, acetone, $0{ }^{\circ} \mathrm{C}$ to rt. (iii) $\mathrm{SOCl}_{2}$. (iv) $\mathrm{P}(\mathrm{OMe})_{3}$, dry THF, $0{ }^{\circ} \mathrm{C}$ to rt. (v) $\mathrm{HPO}(\mathrm{OMe})_{2}, \mathrm{Et}_{2} \mathrm{NH}$, dry THF, $0{ }^{\circ} \mathrm{C}$ to rt; (vi) $\mathrm{TMSBr}, \mathrm{CH}_{2} \mathrm{Cl}_{2}$; then $\mathrm{MeOH}, \mathrm{O}^{\circ} \mathrm{C}$ to rt. phosphites is consecutive, the reaction is carried out in a onepot procedure without isolating the intermediate ketophosphonate 40.

Final deprotection of the amino group was made with $6 \mathrm{~N}$ $\mathrm{HCl}$. The use of hydrazine is also possible and better yields are obtained. By using this variation, alendronate 4, pamidronate $\mathbf{5}$, and neridronate have been prepared as mono- and diesters, which were soluble in water at physiological $\mathrm{pH} .{ }^{\mathbf{1 0 0}}$ The use of tri- and dimethylphosphite led to shorter reaction times. Conjugation of a fluorophore to methyester-protected pamidronate 45, prepared from $\beta$-aminoacid 12, was performed in DMSO in the presence of $N$-methylmorpholine (Scheme 12). Compound 48 was used as a contrast agent in image-guided surgery of large animals. ${ }^{101}$

The use of dimethylphosphite also afforded better results in the synthesis of alendronate 4 reported by Seki in which both P-<smiles>[R]C(=O)O</smiles>

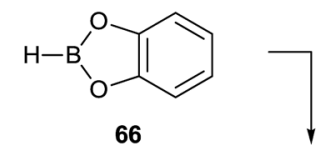<smiles>[R]C(O)(P(=O)(O)O)P(=O)(O)O</smiles>
11<smiles>[R]C(=O)OB1Oc2ccccc2O1</smiles>

67<smiles>[R]=CCCCCC(C)(C)C</smiles>
(68\%) (72\%)<smiles>CN(C)CC(C)(C)[13CH3]</smiles>
(78\%)<smiles>CC(=O)CCCCC(C)(C)C</smiles>
(70\%)<smiles>CC(C)N(C)CCC(C)(C)Oc1ccccc1</smiles><smiles>CC(C)(C)Cc1ccccc1</smiles>

(70\%)<smiles>CNCCC(C)(C)C</smiles><smiles>[TeH4]</smiles><smiles>CC(C)(C)CN</smiles>
$(80 \%)$<smiles>CC(C)Cc1ccc(C(C)(C)C)cc1</smiles>

(62\%)<smiles>CC(C)(C)CCCN</smiles>

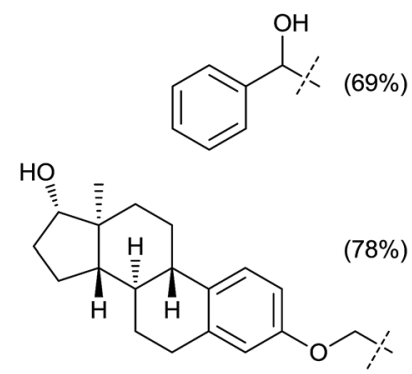

(69\%)

(62\%)

Scheme 16 Reagents and conditions: (i) $\mathrm{THF}$, rt. (ii) $\mathrm{P}\left(\mathrm{OSiMe}_{3}\right)_{3}, 16 \mathrm{~h}$, $25^{\circ} \mathrm{C}$; then $\mathrm{MeOH}, 2 \mathrm{~h}$. 
reagents were compared. Differences were found in the final hydrolysis of the phosphate esters. Ethyl esters showed a lower reactivity towards hydrolysis (Scheme 13). ${ }^{\mathbf{1 0 2}}$

Analogues of alendronic acid $\mathbf{4}$ have been prepared from the common precursor 53 through a practical one-pot, three step methodology. The protection of the 1-hydroxy group was necessary for avoiding mixtures in the acylation step (Scheme 14). ${ }^{103}$

A series of bisphosphonates bearing either the nitrogencontaining NO-donor furoxan (1,2,5-oxadiazole 2-oxide) or the related furazan (1,2,5-oxadiazole) systems in the lateral chain has been prepared by using trimethylphosphite as P-reagent (Scheme 15). ${ }^{\mathbf{1 0 4}}$

Activation of the carboxylic acid as a dioxaborolane can be an alternative to the acid chloride. This approach requires the use of tris(trimethylsilyl)phosphite since dialkylphosphites showed no reaction (Scheme 16). ${ }^{\mathbf{1 0 5}}$ Also in this case a poor reactivity was observed for $N$-hydroxysuccinimide esters towards methyl or phenyl bis(trimethylsilyl)phosphites, in good agreement with previously reported results. ${ }^{\mathbf{1 0 0}}$

\section{Michael addition to tetraethylvinylidenebisphosphonate}

Tetraethyl vinylidenebisphosphonate $\mathbf{6 8}$ is an easily available Michael acceptor and electron-poor dipolarophile/dienophile that results an excellent synthetic intermediate for the synthesis of 1,1-bisphosphonates (Scheme 17). The synthesis of 68 and its application in the preparation of bisphosphonates has been recently reviewed in 2014 by J. B. Rodriguez. ${ }^{106}$ The reader is referred to this excellent compilation for the syntheses of bisphosphonates starting from 68 reported until 2013. Here we survey only those reported after publication of the Rodriguez's review.

The Cu-catalyzed 1,4-conjugate addition of boronic acids and indoles to 68 afforded 1,1-bisphosphonates lacking the gem-OH group (Scheme 18). ${ }^{\mathbf{1 0 7}}$ Whereas the reactions with boronic acids proceeded smoothly in toluene, the addition of indoles can be carried out in polar solvents like 1,2-dichloroethane or water with sodium dodecyl sulfate under micellar conditions.

A series of spiro[indole-pyrrolizine], spiro[indole-indolizine], and spiro[indole-pyrrolidine] gem-bisphosphonates were synthesized through multicomponent reactions between isatins 74, amino acids 75 and 68 in the presence of montmorillonite (Scheme 19). ${ }^{108}$ Acyclic aminoacids can also be used.

The cycloaddition of aromatic nitrones 77 with 68 furnished spiro(isoxazolino)bisphosphonates 78 (Scheme 20).

The reaction, carried out in the absence of solvent and under activation with microwaves takes place in several minutes with good yields. ${ }^{109}$ In all these cases the bisphosphonates prepared by this route lack the 1-hydroxyl group but consist of interesting structurally constrained analogues.

\section{Alkylation of tetralkylmethyl bisphosphonate}

Alkylation of tetraethyl bisphosphonate 79 is an expeditious way of preparing bisphosphonates lacking the 1-hydroxy groups. However, precise reaction conditions must be used in order to avoid elimination reactions. ${ }^{\mathbf{1 1 0}}$ Alkylation of $\mathbf{7 9}$ with farnesyl and geranyl bromides $\mathbf{8 0}$ and $\mathbf{8 1}$ using sodium hydride as a base provided bisphosphonates $\mathbf{8 2 a}, \mathbf{b}$. Further hydrolysis furnished free bisphosphonates 83a,b (Scheme 21). ${ }^{\mathbf{1 1 1}}$

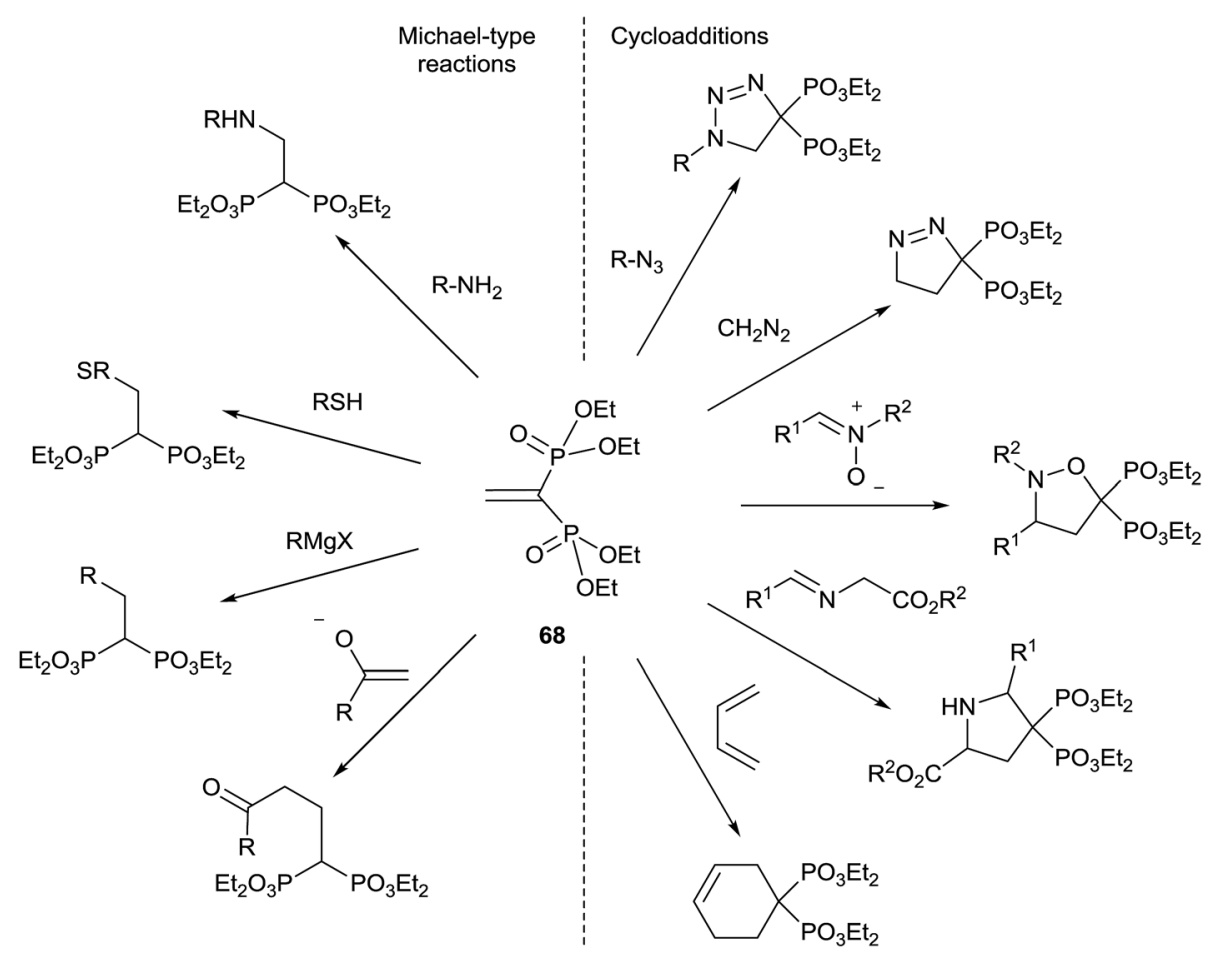

Scheme 17 Synthetic utility of tetraethyl vinylidenebisphosphonate $68 .{ }^{106}$ 

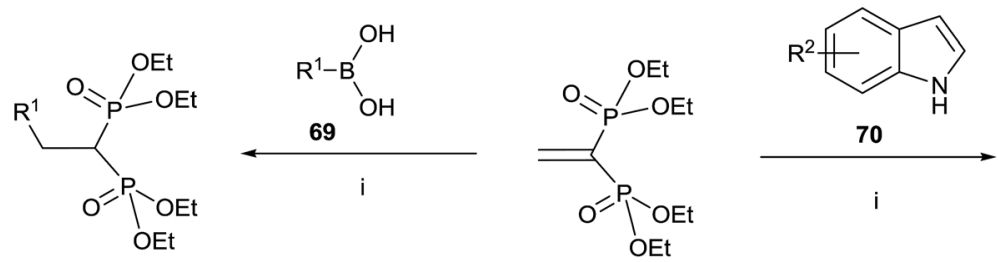

71

68

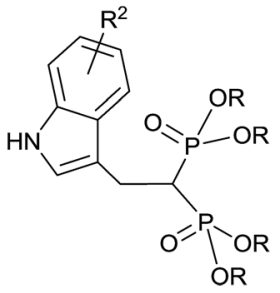

$\begin{array}{ll}72 & \mathrm{R}=\mathrm{Et} \\ 73 & \mathrm{R}=\mathrm{H}\end{array}$ ii $(>98 \%)$

\begin{tabular}{|c|c|c|c|}
\hline $\mathrm{R}^{1}$ & yield $(\%)$ & $\mathrm{R}^{1}$ & yield $(\%)$ \\
\hline $\mathrm{Me}$ & 56 & 3-F-4- $\mathrm{CHOC}_{6} \mathrm{H}_{3}$ & 71 \\
\hline $\mathrm{iPr}$ & 26 & 2-naphthyl & 91 \\
\hline $\mathrm{C}_{6} \mathrm{H}_{5} \mathrm{CH}_{2}$ & 46 & 4-methyl-1-naphthyl & $>98$ \\
\hline 4-tBuC $6 \mathrm{H}_{4}$ & 77 & 2-methoxy-1-naphthyl & 78 \\
\hline 4- $\mathrm{MeOC}_{6} \mathrm{H}_{4}$ & 83 & 2-ethoxy-1-naphthyl & 66 \\
\hline 2,3-diMeOC $6 \mathrm{H}_{3}$ & 96 & 6-hydroxy-2-naphthyl & 69 \\
\hline 3,4-diMeOC $6 \mathrm{H}_{3}$ & 79 & 6-methoxy-2-naphthyl & 91 \\
\hline 4- $\mathrm{Me}_{2} \mathrm{NC}_{6} \mathrm{H}_{4}$ & 74 & 4-Br-1-naphthyl & 83 \\
\hline 4- $\mathrm{NO}_{2} \mathrm{C}_{6} \mathrm{H}_{4}$ & 59 & 3-thienyl & $>98$ \\
\hline $4-\mathrm{BrC}_{6} \mathrm{H}_{4}$ & 59 & 3-benzothienyl & 53 \\
\hline $2-\mathrm{MeC}_{6} \mathrm{H}_{4}$ & 69 & 4-indolyl & 83 \\
\hline
\end{tabular}

$\mathrm{R}^{2}$

yield $(\%)$

$\begin{array}{lc}\text { 1-Me } & 67 \\ \text { 1,2-diMe } & >98 \\ \text { 5-MeO } & 98 \\ \text { 5-MeO-6- } \mathrm{CF}_{3} & 44 \\ \text { 6- } \mathrm{Br}-7-\mathrm{Me} & 84 \\ \text { 5- } \mathrm{COOH} & 50 \\ \text { 5- } \mathrm{COOMe} & 48 \\ \text { 2-Ph } & 77 \\ \left.\text { 2-(4- } \mathrm{C}_{6} \mathrm{H}_{4}\right) & 38\end{array}$

Scheme 18 Reagents and conditions: (i) $\mathrm{Cu}(\mathrm{OTf})_{2}(10 \mathrm{~mol} \%)$, toluene, $18 \mathrm{~h}, 70{ }^{\circ} \mathrm{C}$. (ii) $\mathrm{TMSBr}, 18 \mathrm{~h}, \mathrm{rt}$; then water, $4 \mathrm{~h}, \mathrm{rt}$.<smiles>[R]N1C(=O)C(=O)c2c[R]([H])ccc21</smiles><smiles>O=C(O)C1CCCN1</smiles>

74 $R^{1} \quad R^{2}$ 75

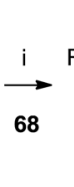<smiles>[R1]c1ccc2c(c1)C1(CCCN([R])C1)CC2(P(=O)(OCC)OCC)P(=O)(OCC)OCC</smiles>

yield (\%)

0.5
0.5
0.5
0.5
2
2
2
2
2
2

\begin{tabular}{lll}
\hline $\mathrm{H}$ & $\mathrm{H}$ & 1 \\
$4-\mathrm{F}$ & $\mathrm{H}$ & 1 \\
$4-\mathrm{Cl}$ & $\mathrm{H}$ & 1 \\
$4-\mathrm{Br}$ & $\mathrm{H}$ & 1 \\
$3-\mathrm{Cl}$ & $\mathrm{H}$ & 1 \\
$4-\mathrm{Me}$ & $\mathrm{H}$ & 1 \\
$4-\mathrm{Me}$ & $\mathrm{Bn}$ & 1 \\
$\mathrm{H}$ & $\mathrm{Bn}$ & 1 \\
$\mathrm{H}$ & $\mathrm{H}$ & 2 \\
$4-\mathrm{F}$ & $\mathrm{H}$ & 2 \\
$4-\mathrm{Cl}$ & $\mathrm{H}$ & 2 \\
$4-\mathrm{Br}$ & $\mathrm{H}$ & 2 \\
$4-\mathrm{Me}$ & $\mathrm{Bn}$ & 2 \\
$\mathrm{H}$ & $\mathrm{Bn}$ & 2
\end{tabular}

$\mathrm{t}(\mathrm{h})$
0.5
0.5
0.5
0.5
2
1
2
2
2
2
2
2
2
2

$\begin{array}{ll}100: 14 & 80 \\ 100: 6 & 92 \\ 100: 22 & 95 \\ 100: 20 & 93 \\ 100: 0 & 57 \\ 100: 24 & 45 \\ 100: 17 & 47 \\ 100: 18 & 44 \\ 100: 46 & 65 \\ 1000: 8 & 45 \\ 100: 0 & 40 \\ 100: 4 & 45 \\ 100: 5 & 40 \\ 100: 8 & 35\end{array}$

Scheme 19 Reagents and conditions: (i) montmorillonite, MeCN, $0.5-$ $2 \mathrm{~h}, 80^{\circ} \mathrm{C}$. (ii) $\mathrm{TMSBr}, 18 \mathrm{~h}, \mathrm{rt}$; then water, $4 \mathrm{~h}$, rt.

On the other hand, using potassium hydride an undesired elimination reaction was observed. ${ }^{\mathbf{1 1 0}}$ By oxidizing the allylic position of the terminal trisubstituted double bond in 80, it was possible to introduce additional substituents at the end of the isoprenoid unit. ${ }^{112}$ Further alkylation of compound $\mathbf{8 0}$ furnished, after hydrolysis, fluorescent
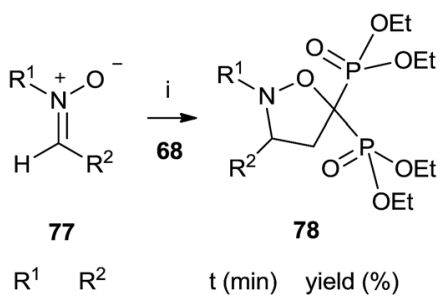

$\begin{array}{llcc}\mathrm{Me} & \mathrm{Ph} & 10 & 75 \\ \mathrm{Me} & 2-\mathrm{ClC}_{6} \mathrm{H}_{4} & 12 & 77 \\ \mathrm{Me} & \text { 3-pyridyl } & 13 & 3 \\ \mathrm{Me} & \text { 2-furyl } & 15 & 68 \\ \mathrm{Bn} & 4-\mathrm{OHC}_{6} \mathrm{H}_{4} & 14 & 74 \\ \mathrm{Bn} & \mathrm{Ph} & 18 & 83 \\ \mathrm{Bn} & 2-\mathrm{ClC}_{6} \mathrm{H}_{4} & 18 & 85 \\ \mathrm{Bn} & 2-\mathrm{FC}_{6} \mathrm{H}_{4} & 20 & 86\end{array}$

Scheme 20 Reagents and conditions: (i) neat, microwave irradiation $200 \mathrm{~W}$.

anthranilate analogue $\mathbf{8 5}$ that showed some inhibition in geranylgeranylation. ${ }^{113}$

Aminobisphosphonate $\mathbf{8 6}$ was alkylated, after protection of the amino group, with methyl 2-bromo acetate. Potassium carbonate in the presence of triethylammonium bromide was used for deprotonating 86. Further deprotection yielded the target bisphosphonate (Scheme 22). ${ }^{114}$

\section{Other methods}

Treatment of $\mathrm{N}$-farnesyl lactams with an excess of base and diethyl phosphorochloridite furnished bisphosphonates 90 in 


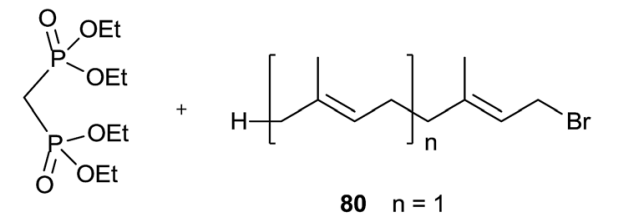

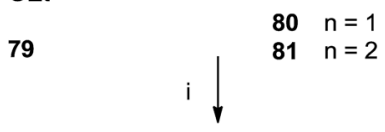<smiles>[R]OP([R])(=O)C(CC=C(C)CCC=C(C)C)P([R])([R])=O</smiles>

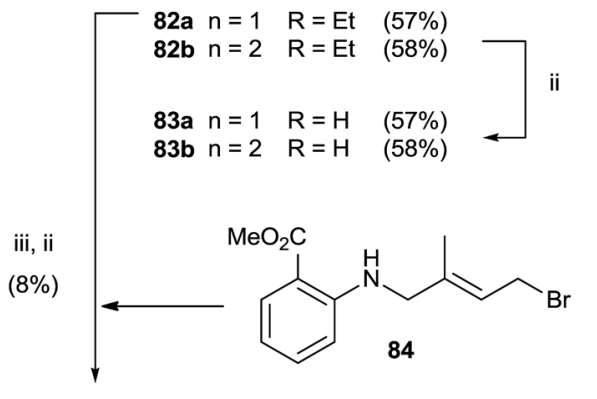<smiles>COC(=O)c1ccccc1NC/C(C)=C/CC(C/C=C(\C)CCC=C(C)C)(P(=O)(O)O)P(=O)(O)O</smiles>

Scheme 21 Reagents and conditions: (i) $\mathrm{NaH}, \mathrm{THF}, 0{ }^{\circ} \mathrm{C}, 1 \mathrm{~h}$; then, 1 day, rt. (ii) $\mathrm{TMSBr}$, collidine, 1 day, rt; then $0.5 \mathrm{M} \mathrm{NaOH} 16$ days, rt. (iii) 84, NaH, THF, 15-crown-5, overnight, rt.

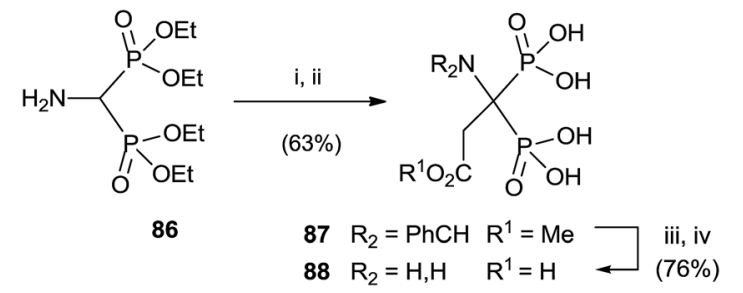

Scheme 22 Reagents and conditions: (i) $m-\mathrm{ClC}_{6} \mathrm{H}_{4} \mathrm{CHO}, \mathrm{MgSO}_{4}$, $\mathrm{CH}_{2} \mathrm{Cl}_{2}$. (ii) $\mathrm{BrCH}_{2} \mathrm{CO}_{2} \mathrm{Me}, \mathrm{Bu}_{4} \mathrm{NBr}, \mathrm{K}_{2} \mathrm{CO}_{3}, \mathrm{MeCN}$. (iii) $1 \mathrm{~N} \mathrm{HCl}, \mathrm{MeCN}$; then $\mathrm{NaOH}$. (iv) $6 \mathrm{~N} \mathrm{HCl}$.

good chemical yields. The methodology can be extended to other carbonyl compounds including amides and lactones although in the case of sterically hindered substrates the expected bisphosphonate is not obtained and other byproducts are formed. Whereas lactams can be phosphorylated with either LDA or LHMDS as a base, the former is preferred for amides and lactones (Scheme 23). ${ }^{\mathbf{1 1 5}}$

Carboxyamide and sulfonamide bisphosphonates are accessible by treating the appropriate amide with trialkyl orthoformate and dialkylphosphites. Subsequent deprotection
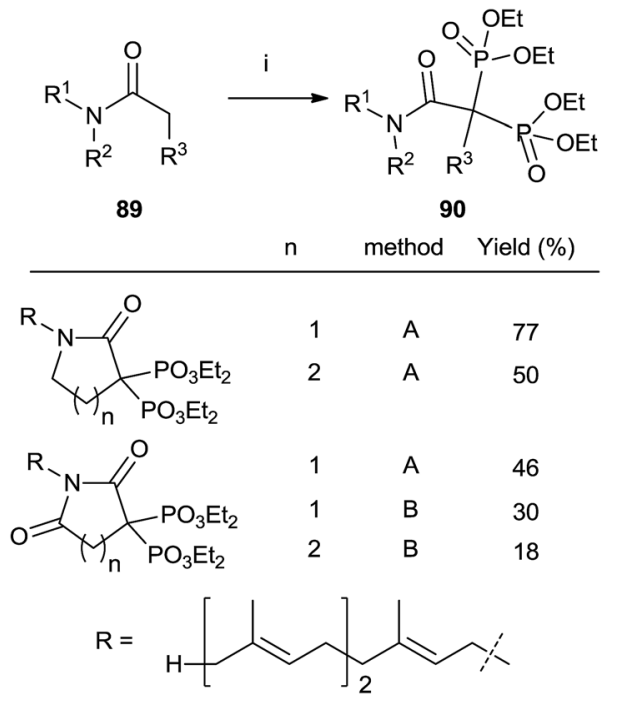

Scheme 23 Reagents and conditions: (i) method A: LDA (2.2 equiv.); then $\mathrm{CIP}(\mathrm{OEt})_{2}$ (2.3 eq.); then $\mathrm{H}_{2} \mathrm{O}_{2}$ (10 eq.). Method B: LHMDS; then $\mathrm{CIP}(\mathrm{OEt})_{2}$; then LHMDS; then CIP(OEt $)_{2}$; then $\mathrm{H}_{2} \mathrm{O}_{2}$ (20 eq.).

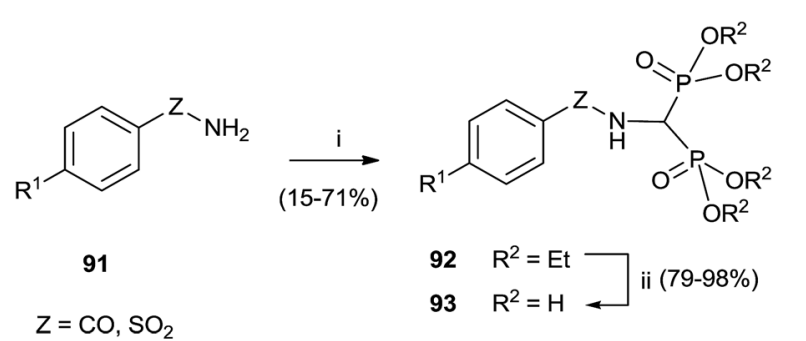

$$
\mathrm{R}^{1}=\mathrm{Me}, \mathrm{Br}, \mathrm{Cl}, \mathrm{MeO}, \mathrm{Ph}, \mathrm{NO}_{2} \quad \mathrm{R}^{2}=\mathrm{Me}, \mathrm{Et}
$$

Scheme 24 Reagents and conditions: (i) $\mathrm{HC}(\mathrm{OR})_{3}, \mathrm{HP}(\mathrm{OR})_{2}, 150^{\circ} \mathrm{C}$. (ii) $\mathrm{BBr}_{3}$, toluene, $\mathrm{MeOH}$, reflux.

under typical conditions furnished bisphosphonates 90 (Scheme 24). ${ }^{116}$

\section{Non-bisphosphonate derivatives}

Non-bisphosphonate antiresorptive agents are represented by molecules with variable dimensions and functional groups.

The presence of a hydroxamate moiety induces a major attitude in terms of metal chelation. ${ }^{\mathbf{1 1 7}}$ Thus, the hydroxamic group is expected to improve the ionic and/or metal chelation interactions with the active site of FPT (Farnesyl Protein Transferase).

The synthesis of $\mathrm{N}$-methyl substituted hydroxamic acid $\mathbf{1 0 3}$ was carried out starting from $\mathrm{N}$-methyl-O-benzyl-hydroxylamine hydrochloride 94 and aspartic acid derivative 95 (Scheme 25). ${ }^{118}$ Deprotection of $\mathbf{9 6}$ and successive coupling of resulting $\mathbf{9 7}$ with tripeptide H-Val-Leu-Ser-OMe $\mathbf{9 8}$ furnished tetrapeptide 99.

Basic hydrolysis with $\mathrm{NaOH}$ of the ester group in 99 provided 100 with $20 \%$ of the free aspartic acid derivative resulting from cleavage of hydroxamic function. The use of sodium carbonate in 2:1 MeOH-water avoided the formation of byproducts maintaining unchanged the chirality. Further deprotection 


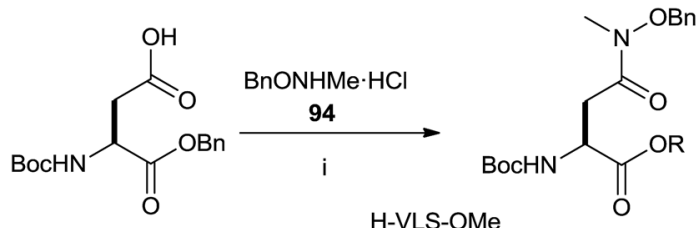

95<smiles>[R]NC(CC(=O)N(C)O[R2])C(=O)N[C@H](C(=O)N[C@@H](CC(C)C)C(=O)N[C@@H](CO)C(=O)O[R1])C(C)C</smiles>

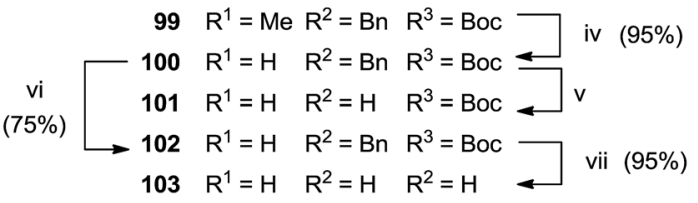

Scheme 25 Reagents and conditions: (i) $\mathrm{CD} 1, \operatorname{Pr}_{2} \mathrm{NEt}$. (ii) $1 \mathrm{~N} \mathrm{NaOH}$, $\mathrm{MeOH}$, (iii) EDC, HOBT, iPr ${ }_{2} \mathrm{NEt}, \mathrm{HVLS}-\mathrm{OMe}$, (iv) $\mathrm{Na}_{2} \mathrm{CO}_{3}$ (1.0), $2: 1$ $\mathrm{MeOH}, \mathrm{H}_{2} \mathrm{O}$. (v) $\mathrm{H}_{2}, 10 \% \mathrm{Pd} / \mathrm{C}, \mathrm{MeOH}$. (vi) Anhydrous $\mathrm{HCl} /$ dioxane, EtOAc. (vii) $\mathrm{H}_{2}, 10 \% \mathrm{Pd} / \mathrm{C}, \mathrm{MeOH}$.

steps gave provided $\mathbf{1 0 3}$ in good yields. In the same work, the authors prepared hydroxamic bisubstrate analogs 114, 116, 118 and $\mathbf{1 2 0}$ by introducing a full farnesyl group on the hydroxamic portion to improve the inhibition of FPT (Scheme 26).

The synthesis was carried out by a multistep sequence utilizing farnesyl bromide $\mathbf{1 0 4}$ as starting material which was transformed into 105 in moderate yield. Acylation of $\mathbf{1 0 5}$ required 2 eq. of the 3-carbomethoxy-propionyl chloride and 3 eq. of DIPEA. Saponification of the resulting 107 furnished intermediate 108 which was coupled with various tripeptides to<smiles>CCCC(C(=O)O)=C(C)C</smiles><smiles>C/C(C(=O)O)=C(\C(=O)O)C(C)C/C=C\CC(C)C</smiles>

Fig. 3 Chaetomellic acids.

give bisubstrates 114, 116, 118 and 120 after opportune removal of protective groups. A critical step in the synthesis was the deprotection of THP group in the presence of farnesyl chain. The problem was solved by using $p$-TsOH although the yields were modest.

In 1993, the chaetomellic acids A and B 121 and 122, classified as alkyl cis-dicarboxylates, were discovered to be potent inhibitors of FPTase because of analogy with the active site of FPP (Fig. 3). ${ }^{119,120}$

Singh and collaborators carried out the synthesis of various chaetomellic acids derivatives through a sequence of three steps. ${ }^{121,122}$ Starting from fatty acid esters $123-125$, the reaction with methylpyruvate in the presence of LDA at $-78{ }^{\circ} \mathrm{C}$ furnished a $1: 1$ diastereomeric mixture of aldol products 126 and 127 (Scheme 27). A $\beta$-elimination reaction of aldol substrates - opportunely protected with a tosyl group produced the tetra-substituted olefins 130-132 via anti or syn periplanar elimination. In the final step, the hydrolysis of ester derivatives by refluxing with a $\mathrm{NaOH}$ solution gave chaetomellic acid analogs 133-135 in moderate yield.

Tucker et al. showed that a large arylthio or aryloxy group adjacent to the cyano function provided compounds with high activity against GGPP and FPT enzymes. ${ }^{\mathbf{1 2 3 , 1 2 4}}$

An approach to the synthesis of inhibitors 139-155 was developed by initial reductive amination of aldehydes 136 with $\mathrm{N}$-Boc-piperazine, titanium iso-propoxide and $\mathrm{NaBH}_{3} \mathrm{CN}$ in THF-EtOH (Scheme 28).

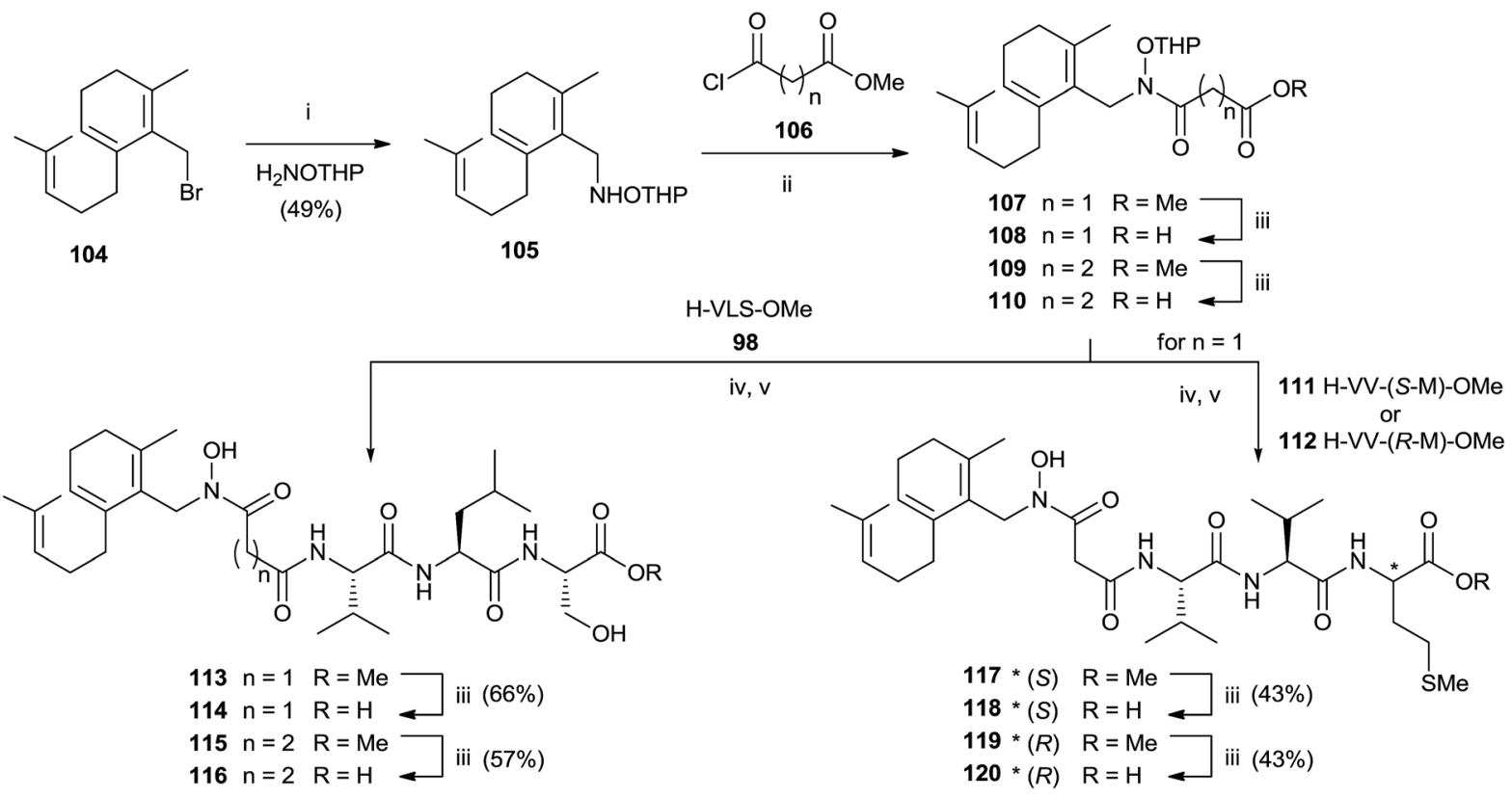

Scheme 26 Reagents and conditions: (i) $\mathrm{NH}_{2} \mathrm{OTHP}$, THF. (ii) $\mathrm{Pr}_{2} \mathrm{NEt}$, THF. (iii) $1 \mathrm{~N} \mathrm{NaOH}, \mathrm{MeOH}$. (iv) EDC, $\mathrm{HOBT}$, iPr $2 \mathrm{NEt}$. (v) $p$ TsOH, MeOH. 
<smiles>[R]C(=O)OC</smiles>

$123 \mathrm{R}=\mathrm{C}_{15} \mathrm{H}_{31}$, methylpalmitate

$124 \mathrm{R}=\mathrm{C}_{17} \mathrm{H}_{33}$, methyloleate, $\Delta^{9,10}$

$125 \mathrm{R}=\mathrm{C}_{13} \mathrm{H}_{27}$, methylmyristate<smiles>[R2]C([R20])(C(=O)OC)C([R2])(C(=O)OC)C([R])([R])C(=O)OC</smiles>

$\begin{array}{ll}126 \mathrm{a}-\mathrm{c} & \mathrm{R}^{2}=\mathrm{H} \\ 128 \mathrm{a}-\mathrm{c} & \mathrm{R}^{2}=\mathrm{Ts}\end{array} \longleftarrow$ ii $\begin{array}{ll}127 \mathrm{a}-\mathrm{c} & \mathrm{R}^{2}=\mathrm{H} \\ 129 \mathrm{a}-\mathrm{c} & \mathrm{R}^{2}=\mathrm{Ts}\end{array} \square$ ii \begin{tabular}{l|l|l} 
iii & $(85 \%)$ \\
& $\downarrow$
\end{tabular}<smiles>[R]C(=O)C(C)=C([R])OC</smiles><smiles>[R]OC(=O)C(=C)C([R])C(=O)O[R]</smiles>

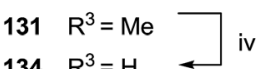<smiles>[R20]C(=O)C(C)=C([R])C(=O)OCC</smiles>

130<smiles>[R]C1=C(C)C(=O)OC1=O</smiles>

$(90-95 \%)$

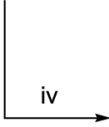

a $\mathrm{R}=\mathrm{C}_{15} \mathrm{H}_{31}$ b $\mathrm{R}=\mathrm{C}_{17} \mathrm{H}_{33}, \Delta^{9,10}$ c $\mathrm{R}=\mathrm{C}_{13} \mathrm{H}_{27}$

133

Scheme 27 Reagents and conditions: (i) LDA, methylpyruvate, THF, $-78{ }^{\circ} \mathrm{C}$. (ii) $p$-Toluenesulfonic anhydride, $\mathrm{CH}_{2} \mathrm{Cl}_{2}, \mathrm{C}_{5} \mathrm{H}_{5} \mathrm{~N}, 2,6$-di-tertbutyl-4-methylpyridine, $40{ }^{\circ} \mathrm{C}$. (iii) $\mathrm{DBU}$, toluene, reflux. (iv) a: $1 \mathrm{~N}$ $\mathrm{NaOH}, \mathrm{MeOH}, \mathrm{THF}, \mathrm{H}_{2} \mathrm{O}, 80^{\circ} \mathrm{C}$. b: $4 \mathrm{~N} \mathrm{HCl}$.

The resulting compounds $\mathbf{1 3 7}$ were deprotected by TFA furnishing the free amines 138 in good yields. The reaction of 138 with appropriate $p$-nitrophenyl carbonate yielded target compounds 139-155 in good yields.

Phosphonocarboxylate (PC), analogues of $N$-BP, characterized by a carboxylic and a phosphonic group on the same carbon, exhibit a chiral structure in contrast to the respective bisphosphonates, increasing the possibility of stereospecificity in their biological activity. ${ }^{\mathbf{1 2 5}-\mathbf{1 2 8}}$

Minodronic acid 156 (Fig. 4) was the first bisphosphonate developed and approved for osteoporosis treatment in Japan and today is available in a number of countries worldwide.

McKenna and co-workers reported, in 2010, the synthesis of the analogue 157 starting from imidazo[1,2- $a$ ]pyridine 158 (Scheme 29). ${ }^{129}$ A Vilsmeier-Haack formylation of 158 furnished aldehyde 159 which was transformed into 160 and then the dehydroaminoester 162. Hydrolysis of 162 and further addition of diethyl phosphite to the resulting 163 furnished protected bisphosphonate $\mathbf{1 6 4}$ that was conveniently deprotected into 156. Resolution of $\mathbf{1 5 6}$ enantiomers

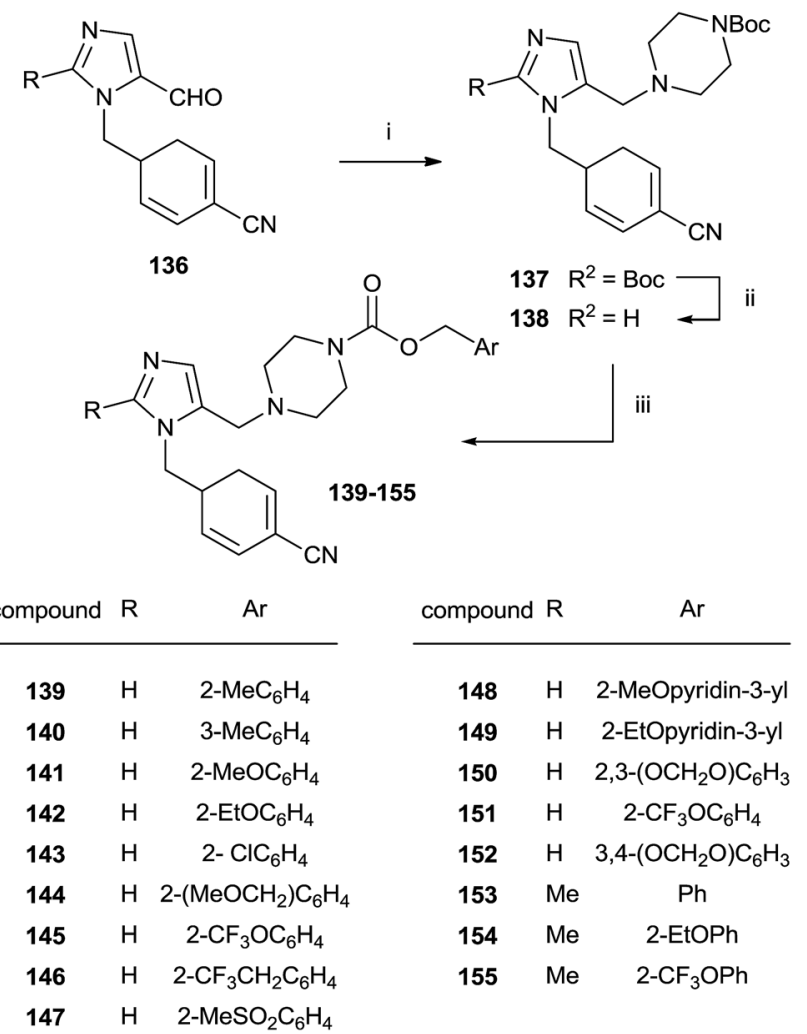

Scheme 28 Reagents and conditions: (i) $\mathrm{Ti}(\mathrm{OPr})_{4}, \mathrm{NaBH}_{3} \mathrm{CN}, \mathrm{N}$-Bocpiperazine/THF-EtOH. (ii) $\mathrm{TFA} / \mathrm{CH}_{2} \mathrm{Cl}_{2}$. (iii) Benzyl-( $p$-nitrophenyl) carbonate, DIEA/DMF, $80^{\circ} \mathrm{C}$.

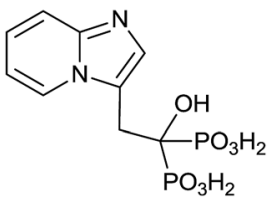

156

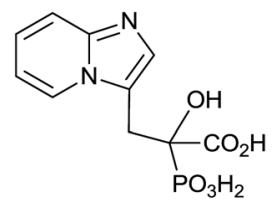

157
Fig. 4 Minodronic acid and analog.

by chiral HPLC furnished the (+)-156 isomer, which revealed a potent inhibitory activity of RGGT.

Replacement of the geminal hydroxyl moiety of PC with a halogen atom allowed to obtaining three $\alpha$-halo derivatives 172-174 with potential biological activity against RGGT. ${ }^{\mathbf{1 3 0}}$ The choice of this substitution had a significant impact to studying the role of the heterocyclic base respect to inhibition of enzyme activity. Starting from 159, a multi-step approach was carried out to synthesize common precursor 167. Halogenation with Selectfluor, $\mathrm{N}$-chlorosuccinimide or $\mathrm{N}$-bromosuccinimide provided haloderivatives 169-171. Further hydrolysis of the ester groups afforded the free acids 172-174 (Scheme 30).

Phosphonocarboxylates can also be approached by routes commonly used for preparing bisphosphonates such as Arbuzov-Michaelis reaction of trialkyl phosphite with $\alpha$-bromoesters, ${ }^{131}$ reaction of diethyl phosphite with $\alpha$-ketoesters, ${ }^{129}$ and reaction of enolates and chlorodialkyl phosphites. ${ }^{132}$ In 
<smiles>O=Cc1cnc2ccccn12</smiles><smiles>CCCCCCCCCCCCCNCC(=O)OCC</smiles><smiles>CCOC(N)=Cc1cnc2ccccn12</smiles>
159<smiles>CCOC(=O)/C(N)=C/c1cnc2ccccn12</smiles><smiles>CCOC(O)=Cc1cnc2ccccn12</smiles>

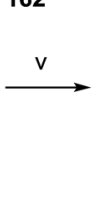

163<smiles>[R]OC(O)(Cc1cnc2ccccn12)C(=O)O</smiles>

$\begin{array}{ll}164 & \mathrm{R}=\mathrm{Et} \\ \mathrm{R} & =\mathrm{H} \rightleftarrows\left(\begin{array}{c}\mathrm{vi} \\ (60 \%)\end{array}\right.\end{array}$

Scheme 29 Reagents and conditions: (i) Vilsmeier reagent, $140{ }^{\circ} \mathrm{C}$. (ii) $\mathrm{EtONa} / \mathrm{EtOH}$, from $-30^{\circ} \mathrm{C}$ to rt, $4 \mathrm{~h}$. (iii) $\mathrm{H}_{2} / 10 \% \mathrm{Pd} / \mathrm{C}, \mathrm{MeOH}, 2.5 \mathrm{~h}$, rt. (iv) $\mathrm{AcOH} / \mathrm{H}_{2} \mathrm{O}(7 / 1 \mathrm{v} / \mathrm{v}), 1.5 \mathrm{~h}, 0{ }^{\circ} \mathrm{C}$. (v) $(\mathrm{EtO})_{2} \mathrm{P}(\mathrm{O}) \mathrm{H}, 70{ }^{\circ} \mathrm{C}, 21 \mathrm{~h}$. (vi) $6 \mathrm{~N}$ $\mathrm{HCl}, 6 \mathrm{~h}$, reflux, (v) and (vi) combined.

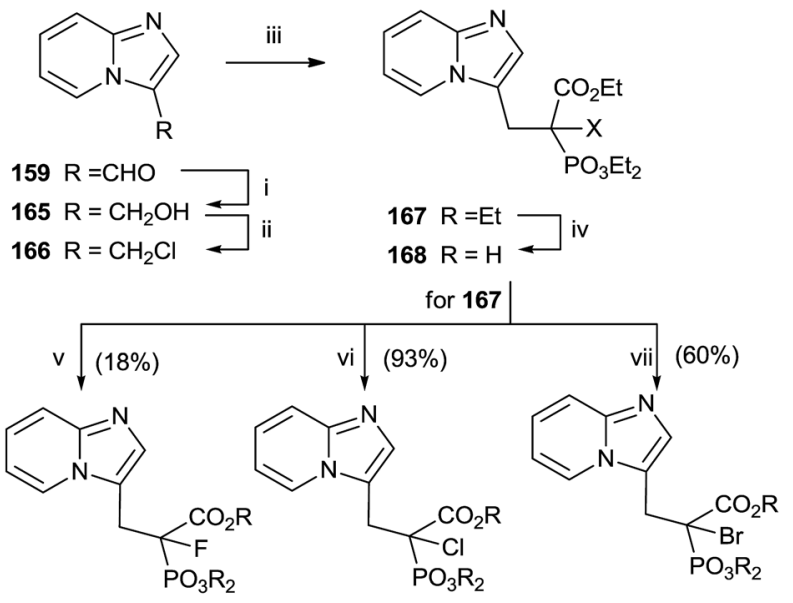

$169 \mathrm{R}=\mathrm{Et} \longrightarrow \quad$ iv $170 \mathrm{R}=\mathrm{Et} \longrightarrow \quad$ iv $171 \mathrm{R}=\mathrm{Et} \longrightarrow$ iv $172 \mathrm{R}=\mathrm{H} \longleftarrow(58 \%) \quad 173 \mathrm{R}=\mathrm{H} \longleftarrow{ }_{(75 \%)} \quad 174 \mathrm{R}=\mathrm{H} \longleftarrow(86 \%)$

Scheme 30 Reagents and conditions: (i) $\mathrm{NaBH}_{4}, \mathrm{MeOH}$, reflux. (ii) $\mathrm{SOCl}_{2}$, reflux, (iii) triethyl phosphonoacetate, $\mathrm{NaH}, \mathrm{DMF}, \mathrm{THF}, 0{ }^{\circ} \mathrm{C}$ to rt. (iv) $12 \mathrm{M} \mathrm{HCl}$, reflux. (v) Selectfluor, $\mathrm{NaH}$, THF. (vi) $\mathrm{N}$-Chlorosuccinimide, $\mathrm{NaH}, \mathrm{THF}$. (vii) $\mathrm{N}$-Bromosuccinimide, $\mathrm{NaH}$, THF.

addition, the insertion of carboxylic function can be performed by using lithium alkylphosphonate and diethyl carbonate ${ }^{\mathbf{1 3 3}}$ or $\mathrm{CO}_{2} \cdot{ }^{134}$ Another methods include alkylation of trialkyl phosphonoacetate $^{\mathbf{1 3 5}}$ and functionalization of trialkyl 2-phosphonoacrylate via Michael-type addition. ${ }^{\mathbf{1 3 6}}$

Recently, Coxon and colleagues used various approaches among those described to synthesize phosphonocarboxylates 175-178 showing some structural diversity (Fig. 5). ${ }^{137}$

Interestingly, the exchange of hydroxyl group with an alkyl chain of different length increased in the hydrophobicity enhancing the activity against GGPPS and FPPS. The synthesis of derivatives $\mathbf{1 8 1}$ was carried starting from $\alpha$-alkyl<smiles>[X]C(Cn1ccnc1)(C(=O)O)[Po](=O)O</smiles>

$$
\begin{array}{ll}
175 a & X=H \\
175 b & X=F
\end{array}
$$$$
\text { 175c } X=\mathrm{OH}
$$<smiles>[X]C(CCN(C)CCCCC)(PO)P(=O)(O)O</smiles><smiles>[X]C([Po])(CCNN)[Po](=O)O</smiles>

177a $\mathrm{n}=1 \quad \mathrm{X}=\mathrm{H}$

177b $n=1 \quad X=F$

177c $\mathrm{n}=1 \quad \mathrm{X}=\mathrm{OH}$

178a $n=2 \quad X=H$

$178 b \quad n=2 \quad X=F$

178c $\mathrm{n}=2 \quad \mathrm{X}=\mathrm{OH}$
Fig. 5 Phophonocarboxylates.

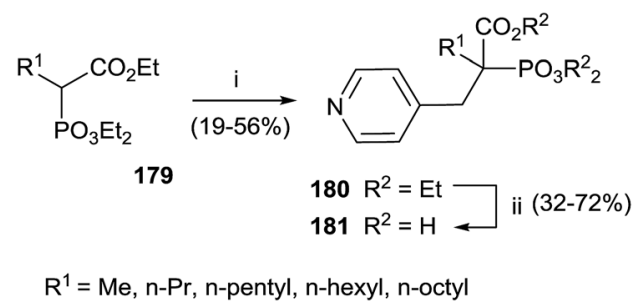

Scheme 31 Reagents and conditions: (i) picolyl chloride, NaH, DMF/ THF. (ii) $12 \mathrm{M} \mathrm{HCl}$, reflux.

phosphonoacetate 179 through an Arbuzov reaction and subsequent alkylation with picolyl chloride (Scheme 31). The corresponding free acids $\mathbf{1 8 1}$ were obtained upon hydrolysis with a $12 \mathrm{M}$ solution of $\mathrm{HCl}$ at reflux.

A category of FPP analogues is constituted from inhibitors with a chain that mimic farnesyl diphosphate or farnesyl group in position C-3. Gibbs et al. have synthesized 3-cyclopropyl-3desmethyl FPP (3-cpFPP) 187 and 3-tert-butyl-3-desmethyl FPP (3-tbFPP), 193 as potential irreversible inactivators of FTPase. ${ }^{138}$ The synthesis of 187 proceeded from 182. Coupling with cyclopropyl cyanocuprate 183 gave 184 in 71\% yield. Reduction of the ester group with DIBALH produced the corresponding alcohol 185 that was chlorinated and immediately treated with tris(tetrabutyl ammonium) hydrogen diphosphate to give 187 (Scheme 32).

Similarly, the synthesis of 193 was carried out through an initial reaction between 182 and the $t$-butyl cyanocuprate 188 . Further steps of reduction, chlorination and pyrophosphorylation furnished 191 (Scheme 33).

Gibbs and co-workers developed a stereoselective synthesis of $c i s$-isoprenoid analogues such as 199 using the vinyl triflate method (Scheme 34). ${ }^{\mathbf{1 3 9 , 1 4 0}}$ The fundamental step was the stereoselective preparation of triflate derivative 196 from the enolate of $\beta$-ketoester 194. The choice of solvent was found to have a significant impact on the trend of the reaction, not only in terms of yield, but also in the stereoselectivity. In fact, the use of DME instead of THF resulted in a loss of stereocontrol, while DMF as reaction solvent promoted only the stereoisomer 
<smiles>[R]C/C(=C\C(=O)OCC)C1CC1</smiles><smiles>[R]#CCC=C(C)CCC=C(C)C</smiles><smiles>[R]C/C(=C/COP(=O)([O-])OP(=O)([O-])[O-])C1CC1</smiles><smiles>N#C[AsH3]</smiles><smiles>[R]C/C(=C/CCl)C1CC1</smiles>

187

186

Scheme 32 Reagents and conditions: (i) cyclopropyl cianocuprate, $\mathrm{Et}_{2} \mathrm{O},-78^{\circ} \mathrm{C}$. (ii) $\mathrm{DIBALH}, \mathrm{PhMe},-78^{\circ} \mathrm{C}$. (iii) $\mathrm{NCS}, \mathrm{Me}_{2} \mathrm{~S}, \mathrm{CH}_{2} \mathrm{Cl}_{2}$. (iv) $\left(\mathrm{Bu}_{4} \mathrm{~N}\right)_{3} \mathrm{HP}_{2} \mathrm{O}_{7}, \mathrm{CH}_{3} \mathrm{CN}$.<smiles>[R]C/C([O])=C/C(=O)OC</smiles>

182<smiles>CCCCC(C)C(C)(C)C</smiles>

188<smiles>[R]C/C(=C/C(=O)OCC)[SiH]([X])CC</smiles>

189<smiles>[Z]C/C=C(/C[R])C(C)(C)C</smiles><smiles>[R]C/C(=C/C(=O)OCC)C(C)(C)C</smiles>

$191 \quad \mathrm{Z}=\mathrm{OH} \longrightarrow$ iv
$192 \mathrm{Z}=\mathrm{Cl}$

190<smiles>[R]C/C(=C/COP(=O)(O)OP(=O)([O-])[O-])C(C)(C)C</smiles>

193

Scheme 33 Reagents and conditions: (i) $t \mathrm{Bu}_{2} \mathrm{Cu}(\mathrm{CN}) \mathrm{Li}_{2},-78{ }^{\circ} \mathrm{C}$. (ii) Reductive elimination. (iii) $\mathrm{DIBALH}, \mathrm{PhMe},-78{ }^{\circ} \mathrm{C}$. (iv) $\mathrm{NCS}, \mathrm{Me}_{2} \mathrm{~S}$, $\mathrm{CH}_{2} \mathrm{Cl}_{2}$. (v) $\left(\mathrm{Bu}_{4} \mathrm{~N}\right)_{3} \mathrm{HP}_{2} \mathrm{O}_{7}, \mathrm{CH}_{3} \mathrm{CN}$.

196 in excellent yield (93\%). Coupling of 196 with tetramethyltin furnished the ester 197 that was reduced with DIBALH to the alcohol 198. Bromination and pyrophosphorylation gave 199.

Compound 194 was employed to synthesize FPP analogues 202 with an alkyl or haloaryl chain in C-3 (Scheme 35). ${ }^{\mathbf{1 4 1}}$

Grignard reagents were made to react with triflate 195 in the presence of copper cyanide with yields from poor to high (3991\%). Further elaboration of intermediates 200 furnished pyrophosphates 202.

The presence of a sulfur atom as thiodiphosphate seems to promote the $(S)$-alkyl thiodiphosphates regioselectivity. Therefore, $(S)$-alkyl isopentenyl and allylic thiodiphosphates 204 and 206-209 were obtained by the procedure illustrated<smiles>[Y]C(C)(CC=C(C)C)C(=O)CC(=O)OCC</smiles>

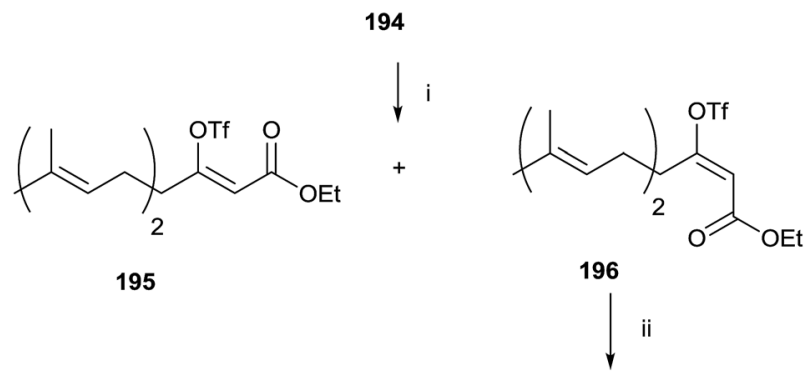<smiles>[2H]C(C/C=C(\C)C(C)C)(C(C)=O)/C(C)=C\C(=O)OCC</smiles>

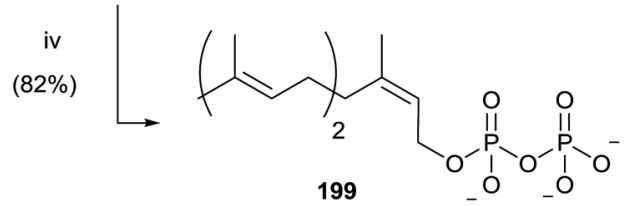

Scheme 34 Reagents and conditions: (i) $\left(\mathrm{Me}_{3} \mathrm{Si}\right)_{2} \mathrm{NK}$, solvent, $-78{ }^{\circ} \mathrm{C}$, $\mathrm{PhN}\left(\mathrm{SO}_{2} \mathrm{CF}_{3}\right)_{2}$. (ii) $\mathrm{Me}_{4} \mathrm{Sn}, \mathrm{Cul}, \mathrm{Pd}\left(\mathrm{AsPh}_{3}\right)_{2}, \mathrm{NMP}, 100{ }^{\circ} \mathrm{C}$. (iii) $\mathrm{DIBALH}$, toluene, $-78{ }^{\circ} \mathrm{C}$. (iv) a: $\mathrm{NBS}, \mathrm{CH}_{2} \mathrm{Cl}_{2}, \mathrm{Me}_{2} \mathrm{~S}$; b: $\left(\mathrm{Bu}_{4} \mathrm{~N}\right)_{3} \mathrm{HP}_{2} \mathrm{O}_{7}, \mathrm{CH}_{3} \mathrm{CN}$.<smiles>CCOC(=O)C=C([O-])C(C)(C)CC=C(C)C</smiles>

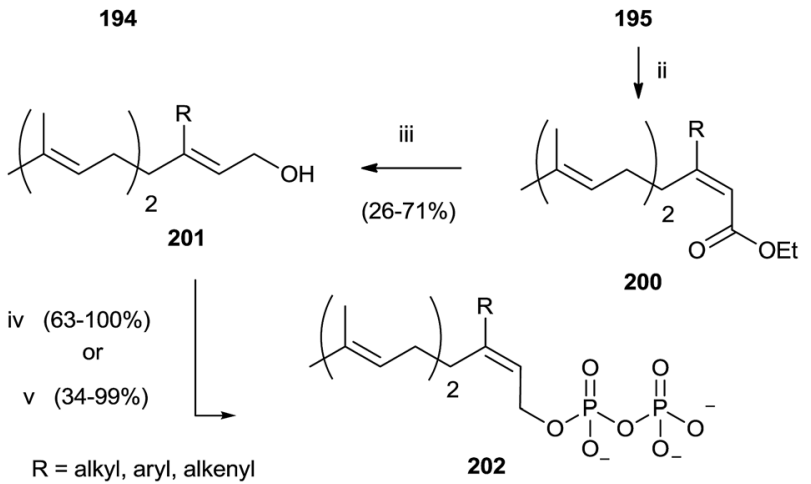

Scheme 35 Reagents and conditions: (i) $\left(\mathrm{Me}_{3} \mathrm{Si}\right)_{2} \mathrm{NK}, \mathrm{THF}, \mathrm{PhN}\left(\mathrm{SO}_{2}{ }^{-}\right.$ $\left.\mathrm{CF}_{3}\right)_{2}$. (ii) $\mathrm{RMgX}, \mathrm{CuCN}$, ether. (iii) DIBALH, toluene. (iv) a: $\mathrm{NBS}, \mathrm{CH}_{2} \mathrm{Cl}_{2}$, $\mathrm{Me}_{2} \mathrm{~S} ; \mathrm{b}:\left(\mathrm{Bu}_{4} \mathrm{~N}\right)_{3} \mathrm{HP}_{2} \mathrm{O}_{7}, \mathrm{CH}_{3} \mathrm{CN}$.

in Scheme $36 .^{\mathbf{1 4 2}}$ The reaction proceeded through slow addition of the isoprenoid derivatives 203 and 205a-d to an acetonitrile solution containing tris(tetra- $n$-butylammonium) thio-pyrophosphate $\left(\mathrm{SPP}_{\mathrm{i}}\right)$. The residue was passed through an ion-exchange column, replacing the tetra- $n$-butylammonium cation with ammonium in order to purify the final product by cellulose chromatography (57-89\% yield).

Quinolines and salicylic derivatives have also been shown to be inhibitors of FFPS. In particular, the combination of 
<smiles>C=C(C)CCO[As]</smiles>

203

204 ISPP<smiles>[R]C(C)=CCSP(=O)([O-])OP(=O)([O-])OC(C)C</smiles>

205a $\mathrm{R}=\mathrm{CH}_{3}$

205b $\mathrm{R}=\mathrm{C}_{6} \mathrm{H}_{11}$

205c R $=\mathrm{C}_{11} \mathrm{H}_{19}$

205d $\mathrm{R}=\mathrm{C}_{16} \mathrm{H}_{27}$

$206 \mathrm{R}=\mathrm{CH}_{3} \quad$ DMASPP

$207 \mathrm{R}=\mathrm{C}_{6} \mathrm{H}_{11} \quad$ GSPP

$208 \mathrm{R}=\mathrm{C}_{11} \mathrm{H}_{19} \quad$ FSPP

$209 \mathrm{R}=\mathrm{C}_{16} \mathrm{H}_{27} \quad$ GGSPP

Scheme 36 Reagents and conditions: (i) Tris-(tetra- $n$-butylammonium)thiopyro-phosphate, $\mathrm{CH}_{3} \mathrm{CN}$. (ii) Dowex AG 50W-X8 $\left(\mathrm{NH}_{4}{ }^{+}\right.$ form).

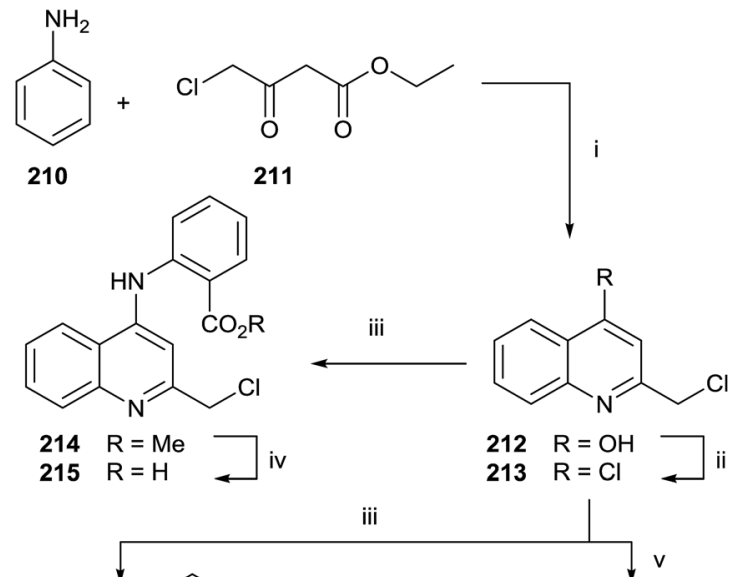<smiles>CCOc1ccccc1OCc1cc(Nc2ccccc2C(C)=O)c2ccccc2n1</smiles><smiles>[R]Oc1ccccc1OCc1cc(Cl)c2ccccc2n1</smiles>

$218 R=E t, R^{\prime}=M$

$\begin{array}{ll}216 & R=E t \quad \square \text { iv } \\ 217 & R=H\end{array}$ $219 \mathrm{R}=\mathrm{R}^{\prime}=\mathrm{H}$

Scheme 37 Reagents and conditions: (i) PPA, $130{ }^{\circ} \mathrm{C}, 1 \mathrm{~h}$. (ii) $\mathrm{POCl}_{3}$ $100{ }^{\circ} \mathrm{C}, 3$ h. (iii) Methyl 2-aminobenzoate, $\mathrm{C}_{2} \mathrm{H}_{5} \mathrm{OH}$, conc. $\mathrm{HCl}, 5$ h. (iv) $\mathrm{THF} / \mathrm{MeOH}$, $\mathrm{LiOH}, 3$ h. (v) Ethyl-2-hydroxybenzoate, $\mathrm{K}_{2} \mathrm{CO}_{3}, \mathrm{CH}_{3} \mathrm{CN}$, $90^{\circ} \mathrm{C}, 5 \mathrm{~h}$

quinolines with zoledronate seems to amplify the inhibition effect respect to the individual inhibitor. Therefore, a series of quinoline derivatives was synthesized starting from aniline 210 and ethyl 4chloroacetoacetate 211 in PPA at $130{ }^{\circ} \mathrm{C}$ (Scheme 37). ${ }^{143}$

The crude mixture was directly chlorinated by $\mathrm{POCl}_{3}$ at $100{ }^{\circ} \mathrm{C}$. The resulting intermediate 213 was used without further purification in the following reaction with methyl 2-aminobenzoate 214 or ethyl 2-hydroxybenzoate 216. Different reaction routes allowed obtaining three different quinoline analogues 215, 217 and 219.

In 2015, Marzinzik et al. synthesized a library of salicylic acid derivatives exploiting the presence of a bromine atom in the<smiles>[R]Oc1cc(Br)ccc1C(=O)Oc1ccc(Br)cc1C(=O)O</smiles>

220

221<smiles>[R]c1ccc([Al])cc1</smiles><smiles>COc1ccc2cc(I)ccc2c1</smiles>
(28\%)

$$
\begin{array}{ll}
\mathrm{R}=\mathrm{H} & (40 \%) \\
\mathrm{R}=\mathrm{F} & (64 \%) \\
\mathrm{R}=\mathrm{CH}_{2} \mathrm{OH} & (57 \%) \\
\mathrm{R}=\mathrm{CONH}_{2} & (9 \%) \\
\mathrm{R}=\mathrm{NHAc} & (34 \%) \\
\mathrm{R}=\mathrm{NHPh} & (26 \%) \\
\mathrm{R}=\mathrm{CONHMe}^{(34 \%)} \\
\mathrm{R}=\mathrm{NHSO}_{2} \mathrm{Me}(63 \%)
\end{array}
$$<smiles>CC(C)(C)Cc1cccc2ccccc12</smiles>

$(79 \%)$
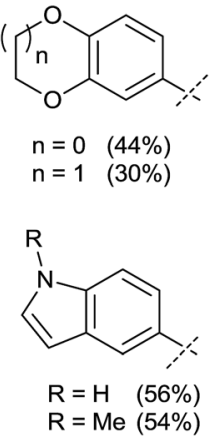

Scheme 38 Reagents and conditions: (i) 1: boronic acid, $\mathrm{Pd}\left(\mathrm{PPh}_{3}\right) \mathrm{Cl}_{2}$, $\mathrm{Na}_{2} \mathrm{CO}_{3}, \mathrm{DME} / \mathrm{EtOH}, \mathrm{H}_{2} \mathrm{O}, \mathrm{MW}\left(110^{\circ} \mathrm{C}\right), 10 \mathrm{~min}$. (ii) $\mathrm{LiOH}, \mathrm{MeOH} / \mathrm{THF}$, $\mathrm{MW}\left(110^{\circ} \mathrm{C}\right), 12 \mathrm{~min}$.<smiles>O=C(O)c1cc2c(-c3cccc4[nH]ccc34)cccc2[nH]1</smiles><smiles>[R]c1cc(-c2cccc3ccccc23)c2nc(C(=O)O)ccc2c1[R]</smiles>

222

$\begin{array}{lll}\mathbf{2 2 3} & \mathrm{R}^{1}=\mathrm{H} & \mathrm{R}^{2}=\mathrm{H} \\ \mathbf{2 2 4} & \mathrm{R}^{1}=\text { pyrrol-2-yl } & \mathrm{R}^{2}=\mathrm{H} \\ \mathbf{2 2 5} & \mathrm{R}^{1}=\text { 3-thienyl } & \mathrm{R}^{2}=\mathrm{H} \\ \mathbf{2 2 6} & \mathrm{R}^{1}=\mathrm{NH}_{2} & \mathrm{R}^{2}=\mathrm{H} \\ \mathbf{2 2 7} & \mathrm{R}^{1}=\mathrm{NH}_{2} & \mathrm{R}^{2}=\mathrm{OEt} \\ \mathbf{2 2 8} & \mathrm{R}^{1}=\mathrm{NHCO}_{2} \mathrm{Et} & \mathrm{R}^{2}=\mathrm{H}\end{array}$

Fig.6 Quinoline substrates.

para position of the carboxylic acid in the phenyl ring. ${ }^{\mathbf{1 4 4}}$ Compound $\mathbf{2 2 0}$ represented the starting point to synthesize a variety of salicylic acid analogues through an initial reaction with boronic acid by microwave irradiation. The final step with $\mathrm{LiOH}$ in $\mathrm{MeOH} / \mathrm{THF}$ was promoted by the use of microwaves yielding substrates 221 (Scheme 38).

The same authors prepared a variety quinoline substrates 222-228 via different synthetic strategies (Fig. 6).

In particular, a unique method allowed the simultaneous synthesis of three active quinoline compounds 226-228 starting from nitration of 8-bromoquinoline-2(1H)-one 229 (Scheme 39).

Suzuki coupling of the crude of the nitro-derivatives $\mathbf{2 3 0}$ with naphthyl boronate gave 231 that was converted in 232 with $\mathrm{POCl}_{3}$ in the presence of $\mathrm{N}, \mathrm{N}$-dimethylaniline and $\mathrm{Et}_{4} \mathrm{NCl}$. Palladium-catalyzed carbonylation and reduction of nitro group of 232 produced the intermediate esters 233-235 in moderate yield that were hydrolyzed with $\mathrm{LiOH}$ to perform quinolines 226-228. 
<smiles>O=c1ccc2cc([N+](=O)[O-])cc(Br)c2[nH]1</smiles>

229

\section{0}

ii $\downarrow(80-92 \%)$<smiles>O=[N+]([O-])c1cc(-c2cccc3ccccc23)c2nc(Cl)ccc2c1</smiles>

$\longleftarrow$<smiles>O=c1ccc2cc([N+](=O)[O-])cc(-c3cccc4ccccc34)c2[nH]1</smiles>

231

232

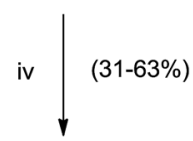<smiles>[R]OC(=O)c1ccc2cc(NC(=O)OCC)cc(-c3cccc4ccccc34)c2n1</smiles><smiles>[R]OC(=O)c1ccc2c(OCC)c(N)cc(-c3cccc4ccccc34)c2n1</smiles><smiles></smiles>

$234 \mathrm{R}=\mathrm{Et}$ $227 \mathrm{R}=\mathrm{H}$

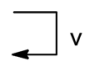

Scheme 39 Reagents and conditions: (i) fuming $\mathrm{HNO}_{3}, \mathrm{TFA}$, from $0^{\circ} \mathrm{C}$ to rt. (ii) $\mathrm{K}_{2} \mathrm{CO}_{3}$, boronic acid, $\left[\left(\mathrm{C}_{6} \mathrm{H}_{5}\right)_{3} \mathrm{P}\right]_{2} \mathrm{PdCl}_{2}, \mathrm{DMF} / \mathrm{H}_{2} \mathrm{O}, 80-92{ }^{\circ} \mathrm{C}$. (iii) $\mathrm{POCl}_{3}, \mathrm{Et}_{4} \mathrm{NCl}, \mathrm{N}, \mathrm{N}$-dimethylaniline, $\mathrm{CH}_{3} \mathrm{CN}$. (iv) $\mathrm{CO},\left[\left(\mathrm{C}_{6} \mathrm{H}_{5}\right)_{3}\right.$ $\mathrm{Pl}_{2} \mathrm{PdCl}_{2}, \mathrm{Et}_{3} \mathrm{~N}, \mathrm{EtOH}, 110{ }^{\circ} \mathrm{C}$. (v) $\mathrm{LiOH}, \mathrm{H}_{2} \mathrm{O} /$ dioxane.

\section{Concluding remarks}

Historically, bisphosphonates are benchmark drugs for the treatment of a variety of bone disorders including osteoporosis and bone metastasis. Their inhibitory activity of the isoprenoid biosynthesis resulted in other important applications as modulators of the metabolism of several protozoa parasites thus also being potential therapeutic agents for the treatment of trypanosomiasis (Chagas disease), leishmaniasis, toxoplasmosis and malaria. Bisphosphonates could also be useful in the treatment of other diseases such as breast cancer, myeloma multiple and progeria. Both clinical success in bone disorders and expectative for other diseases prompted the enormous synthetic activity directed to the preparation of bisphosphonates and more recently, nitrogen-containing bisphosphonates which are demonstrated better biological properties. In general, the reaction of carboxylic acids with phosphorous reagents like $\mathrm{POCl}_{3}$ is the preferred approach to bisphophonates. The reaction, however, is very sensitive to steric hindrance and in such cases an Arbuzov-type reaction results more advisable. More recently, the use of tetraethylvinylidenebisphosphonate as the source of phosphorylated part of the molecule has facilitated enormously the access to a variety of bisphophonates. Moreover, the use of such a reagent presented a high tolerance to a variety of functional groups. For the particular case of bisphosphonates lacking the hydroxyl group the alkylation of tetralkylmethyl bisphosphonate is preferred; however, elimination reactions are common undesired lateral processes that, on the other hand, can be eliminated by using precise reaction conditions.

The presence of two phosphate units, in addition to difficult manipulation and purification, limits the oral bioavailability and contribute to undesired side-effects. In this respect, novel bisphosphonate analogues that selectively target FPPS and GGPPS enzymes might provide notable advantages over the currently used drugs and this is now the subject of intense investigation in medicinal chemistry and chemical biology. Achieving this target implies to have at disposition a series of synthetic strategies that allow not only the preparation of the target compound but also structural variations of the parent compound that provide lead compounds for further studies for treatment of the several diseases related to isoprenoid biosynthesis.

\section{Acknowledgements}

This work was supported by the MINECO and FEDER Program (Madrid, Spain, project CTQ2016-76155-R) and the Gobierno de Aragon (Zaragoza, Spain. Bioorganic Chemistry Group. E-10). We thank the Italian Ministry of University and Scientific Research (MIUR) for a doctoral grant and the University of Calabria for financial support.

\section{Notes and references}

1 B. M. Lange, T. Rujan, W. Martin and R. Croteau, Proc. Natl. Acad. Sci. U. S. A., 2000, 97, 13172-13177.

2 R. E. Summons, L. L. Jahnke, J. M. Hope and G. A. Logan, Nature, 1999, 400, 554-557.

3 J. C. Sacchettini and C. D. Poulter, Science, 1997, 277, 17881789.

4 M. Rodriguez-Concepcion, Methods Mol. Biol., 2014, 1153, 1-5.

5 D. Tholl, Adv. Biochem. Eng./Biotechnol., 2015, 148, 63-106.

6 P. Sakthivel, N. Sharma, P. Klahn, M. Gereke and D. Bruder, Curr. Med. Chem., 2016, 23, 1549-1570.

7 Natural products and cancer signaling: isoprenoids, polyphenols and flavonoids, ed. S. Z. Bathaie and F. Tamanoi, Academic Press, London, 2014. 
8 T. Kuzuyama and H. Seto, Proc. Jpn. Acad., Ser. B, 2012, 88, 41-52.

9 M. Galata and S. Mahmoud, Stud. Nat. Prod. Chem., 2012, 37, 135-171.

10 Biotechnology of Isoprenoids, ed. J. Schrader and J. Bohlmann, Springer, Heidelberg, 2015.

11 A. Boronat and M. Rodriguez-Concepcion, Adv. Biochem. Eng./Biotechnol., 2015, 148, 3-18.

12 D.-K. Ro, in Plant Metabolism and Biotechnology, ed. H. Ashihara, A. Crozier and A. Komamine, John Wiley \& Sons, Ltd, Chichester, UK, 2011, pp. 217-240.

13 E. Oldfield, Acc. Chem. Res., 2010, 43, 1216-1226.

14 J. Park, A. N. Matralis, A. M. Berghuis and Y. S. Tsantrizos, Front. Chem., 2014, 2, 1-21.

15 I. Hale, P. M. O'Neill, N. G. Berry, A. Odom and R. Sharma, MedChemComm, 2012, 3, 418-433.

16 A. M. Guggisberg, R. E. Amthor and A. R. Odom, Eukaryotic Cell, 2014, 13, 1348-1359.

17 T. Qidwai, F. Jamal, M. Y. Khan and B. Sharma, Biochem. Res. Int., 2014, 657189.

18 V. G. Duschak, Recent Pat. Anti-Infect. Drug Discovery, 2011, 6, 216-259.

19 M. Sanchez-Sanchez, G. Rivera, E. A. Garcia and V. Bocanegra-Garcia, Mini-Rev. Org. Chem., 2016, 13, 227243.

20 M. O. Kim, X. Feng, F. Feixas, W. Zhu, S. Lindert, S. Bogue, W. Sinko, C. de Oliveira, G. Rao, E. Oldfield and J. A. McCammon, Chem. Biol. Drug Des., 2015, 85, 756769.

21 W. Wang and E. Oldfield, Angew. Chem., Int. Ed., 2014, 53, 4294-4310.

22 J. S. Burg and P. J. Espenshade, Prog. Lipid Res., 2011, 50, 403-410.

23 U. T. T. Nguyen, A. Goodall, K. Alexandrov and D. Abankwa, Protein Rev., 2011, 13, 1-37.

24 J. Desai, Y. Wang, K. Wang, S. R. Malwal and E. Oldfield, ChemMedChem, 2016, 11, 2205-2215.

25 S. A. Holstein and R. J. Hohl, Enzymes, 2011, 30, 301-319.

26 A. Srivastava, P. Mukherjee, P. V. Desai, M. A. Avery and B. L. Tekwani, Infect. Disord.: Drug Targets, 2008, 8, 16-30.

27 K. M. Swanson and R. J. Hohl, Curr. Cancer Drug Targets, 2006, 6, 15-37.

28 T. Todenhoefer, J. Hennenlotter, U. Kuehs, V. Gerber, G. Gakis, U. Vogel, S. Aufderklamm, A. Merseburger, J. Knapp, A. Stenzl and C. Schwentner, World J. Urol., 2013, 31, 345-350.

29 M. K. Tsoumpra, J. R. Muniz, B. L. Barnett, A. A. Kwaasi, E. S. Pilka, K. L. Kavanagh, A. Evdokimov, R. L. Walter, F. Von Delft, F. H. Ebetino, U. Oppermann, R. G. G. Russell and J. E. Dunford, Bone, 2015, 81, 478-486.

30 K. L. Kavanagh, K. Guo, J. E. Dunford, X. Wu, S. Knapp, F. H. Ebetino, M. J. Rogers, R. G. G. Russell and U. Oppermann, Proc. Natl. Acad. Sci. U. S. A., 2006, 103, 7829-7834.

31 R. Eastell, J. S. Walsh, N. B. Watts and E. Siris, Bone, 2011, 49, 82-88.

32 I. R. Reid and D. J. Hosking, Bone, 2011, 49, 89-94.
33 M. Colina, G. Ciancio and F. Trotta, Clin. Med.: Ther., 2009, 1, 1451-1456.

34 M. Wilke, A. Gobel, M. Rauner, P. Benad-Mehner, D. Rachner Tilman, N. Schutze, S. Fussel, P. Hadji and C. Hofbauer Lorenz, Journal of Bone Oncology, 2014, 3, 1017.

35 C.-Q. Du, X.-W. Liu, G.-Z. Zeng, H.-F. Jin and L.-J. Tang, Int. J. Mol. Med., 2015, 35, 1767-1772.

36 C. M. Szabo, Y. Matsumura, S. Fukura, M. B. Martin, J. M. Sanders, S. Sengupta, J. A. Cieslak, T. C. Loftus, C. R. Lea, H.-J. Lee, A. Koohang, R. M. Coates, H. Sagami and E. Oldfield, J. Med. Chem., 2002, 45, 2185-2196.

37 J. D. Artz, A. K. Wernimont, J. E. Dunford, M. Schapira, A. Dong, Y. Zhao, J. Lew, R. G. G. Russell, F. H. Ebetino, U. Oppermann and R. Hui, J. Biol. Chem., 2011, 286, 3315-3322.

38 K. L. Kavanagh, J. E. Dunford, G. Bunkoczi, R. G. G. Russell and U. Oppermann, J. Biol. Chem., 2006, 281, 2200422012.

39 M. F. Mabanglo, M. A. Hast, N. B. Lubock, H. W. Hellinga and L. S. Beese, Protein Sci., 2014, 23, 289-301.

40 R. G. G. Russell, Ann. N. Y. Acad. Sci., 2006, 1068, 367-401. 41 R. G. G. Russell, Bone, 2011, 49, 2-19.

42 L. Widler, W. Jahnke and J. R. Green, Anti-Cancer Agents Med. Chem., 2012, 12, 95-101.

43 S. Nishida, Y. Fujii, S. Yoshioka, S. Kikuichi, M. Tsubaki and K. Irimajiri, Life Sci., 2003, 73, 2655-2664.

44 S. E. Sen, L. Wood, R. Jacob, A. Xhambazi, B. Pease, A. Jones, T. Horsfield, A. Lin and M. Cusson, Insect Biochem. Mol. Biol., 2015, 63, 113-123.

45 M. J. Rogers, J. C. Crockett, F. P. Coxon and J. Monkkonen, Bone, 2011, 49, 34-41.

46 W. Jahnke, J.-M. Rondeau, S. Cotesta, A. Marzinzik, X. Pelle, M. Geiser, A. Strauss, M. Goette, F. Bitsch, R. Hemmig, C. Henry, S. Lehmann, J. F. Glickman, T. P. Roddy, S. J. Stout and J. R. Green, Nat. Chem. Biol., 2010, 6, 660-666. 47 S. L. Graham, Expert Opin. Ther. Pat., 1995, 5, 1269-1285.

48 A. J. Roelofs, K. Thompson, F. H. Ebetino, M. J. Rogers and F. P. Coxon, Curr. Pharm. Des., 2010, 16, 2950-2960.

49 K. Thompson and M. J. Rogers, Clin. Rev. Bone Miner. Metab., 2007, 5, 130-144.

50 M. J. Rogers, Curr. Pharm. Des., 2003, 9, 2643-2658.

51 M. T. Drake, B. L. Clarke and S. Khosla, Mayo Clin. Proc., 2008, 83, 1032-1045.

52 J. B. Rodriguez, B. N. Falcone and S. H. Szajnman, Expert Opin. Drug Discovery, 2016, 11, 307-320.

53 S. Sun and C. E. McKenna, Expert Opin. Ther. Pat., 2011, 21, 1433-1451.

54 G. R. Kieczykowski, R. B. Jobson, D. G. Melillo, D. F. Reinhold, V. J. Grenda and I. Shinkai, J. Org. Chem., 1995, 60, 8310-8312.

55 E. Maltezou, M. Stylianou, S. Roy, C. Drouza and A. D. Keramidas, Bioinorg. Chem. Appl., 2010, 563875.

56 M. B. Martin, J. S. Grimley, J. C. Lewis, H. T. Heath III, B. N. Bailey, H. Kendrick, V. Yardley, A. Caldera, R. Lira, J. A. Urbina, S. N. J. Moreno, R. Docampo, S. L. Croft and E. Oldfield, J. Med. Chem., 2001, 44, 909-916. 
57 E. Migianu-Griffoni, I. Chebbi, S. Kachbi, M. Monteil, O. Sainte-Catherine, F. Chaubet, O. Oudar and M. Lecouvey, Bioconjugate Chem., 2014, 25, 224-230.

58 Y. Xie, H. Ding, L. Qian, X. Yan, C. Yang and Y. Xie, Bioorg. Med. Chem. Lett., 2005, 15, 3267-3270.

59 P. A. Turhanen and J. J. Vepsalainen, Beilstein J. Org. Chem., 2006, 2(2), DOI: 10.1186/1860-5397-2-2.

60 E. Palma, J. D. G. Correia, B. L. Oliveira, L. Gano, I. C. Santos and I. Santos, Dalton Trans., 2011, 40, 2787-2796.

$61 \mathrm{H}$. Schott, D. Goltz, T. C. Schott, C. Jauch and R. A. Schwendener, Bioorg. Med. Chem., 2011, 19, 3520-3526.

62 M. Lecouvey, C. Dufau, D. El Manouni and Y. Leroux, Nucleosides Nucleotides, 1999, 18, 2109-2120.

63 Y. Yang, N. Liu, J. Liao, M. Pu, Y. Liu, M. Wei and J. Jin, J. Radioanal. Nucl. Chem., 2010, 283, 329-335.

64 G. Xu, Y. Xie and X. Wu, Org. Prep. Proced. Int., 2004, 36, 185-187.

65 D. A. Mustafa, B. A. Kashemirov and C. E. McKenna, Tetrahedron Lett., 2011, 52, 2285-2287.

66 S. Deprele, B. A. Kashemirov, J. M. Hogan, F. H. Ebetino, B. L. Barnett, A. Evdokimov and C. E. McKenna, Bioorg. Med. Chem. Lett., 2008, 18, 2878-2882.

67 M. B. Martin, J. M. Sanders, H. Kendrick, K. de Luca-Fradley, J. C. Lewis, J. S. Grimley, E. M. Van Brussel, J. R. Olsen, G. A. Meints, A. Burzynska, P. Kafarski, S. L. Croft and E. Oldfield, J. Med. Chem., 2002, 45, 2904-2914.

68 J. M. Sanders, A. O. Gómez, J. Mao, G. A. Meints, E. M. Van Brussel, A. Burzynska, P. Kafarski, D. González-Pacanowska and E. Oldfield, J. Med. Chem., 2003, 46, 5171-5183.

69 S. Ghosh, J. M. W. Chan, C. R. Lea, G. A. Meints, J. C. Lewis, Z. S. Tovian, R. M. Flessner, T. C. Loftus, I. Bruchhaus, H. Kendrick, S. L. Croft, R. G. Kemp, S. Kobayashi, T. Nozaki and E. Oldfield, J. Med. Chem., 2004, 47, 175-187.

70 J. M. Sanders, S. Ghosh, J. M. W. Chan, G. Meints, H. Wang, A. M. Raker, Y. Song, A. Colantino, A. Burzynska, P. Kafarski, C. T. Morita and E. Oldfield, J. Med. Chem., 2004, 47, 375-384.

71 Y. Ling, G. Sahota, S. Odeh, J. M. W. Chan, F. G. Araujo, S. N. J. Moreno and E. Oldfield, J. Med. Chem., 2005, 48, 3130-3140.

72 J. M. Sanders, Y. Song, J. M. W. Chan, Y. Zhang, S. Jennings, T. Kosztowski, S. Odeh, R. Flessner, C. Schwerdtfeger, E. Kotsikorou, G. A. Meints, A. O. Gomez, D. GonzalezPacanowska, A. M. Raker, H. Wang, E. R. van Beek, S. E. Papapoulos, C. T. Morita and E. Oldfield, J. Med. Chem., 2005, 48, 2957-2963.

73 C. K. M. Chen, M. P. Hudock, Y. Zhang, R.-T. Guo, R. Cao, J. H. No, P.-H. Liang, T.-P. Ko, T.-H. Chang, S.-c. Chang, Y. Song, J. Axelson, A. Kumar, A. H. J. Wang and E. Oldfield, J. Med. Chem., 2008, 51, 5594-5607.

74 J. Mao, S. Mukherjee, Y. Zhang, R. Cao, J. M. Sanders, Y. Song, Y. Zhang, G. A. Meints, Y. G. Gao, D. Mukkamala, M. P. Hudock and E. Oldfield, J. Am. Chem. Soc., 2006, 128, 14485-14497.

75 L.-S. Zhou, K.-W. Yang, L. Feng, J.-M. Xiao, C.-C. Liu, Y.-L. Zhang and M. W. Crowder, Bioorg. Med. Chem. Lett., 2013, 23, 949-954.
76 G. Keglevich, A. Grun, R. Kovacs, K. Koos, B. Szolnoki, S. Garadnay, J. Neu, L. Drahos and I. Greiner, Lett. Drug Des. Discovery, 2012, 9, 345-351.

77 H. R. Hudson, N. J. Wardle, S. W. A. Bligh, I. Greiner, A. Grun and G. Keglevich, Mini-Rev. Med. Chem., 2012, 12, 313-325.

78 R. Kovacs, A. Gruen, S. Garadnay, I. Greiner and G. Keglevich, Green Process. Synth., 2014, 3, 111-116.

79 G. Keglevich, A. Gruen, K. Aradi, S. Garadnay and I. Greiner, Tetrahedron Lett., 2011, 52, 2744-2746.

80 M. Recher, A. P. Barboza, Z.-H. Li, M. Galizzi, M. FerrerCasal, S. H. Szajnman, R. Docampo, S. N. J. Moreno and J. B. Rodriguez, Eur. J. Med. Chem., 2013, 60, 431-440.

81 K. Troev, P. Todorov, E. Naydenova, V. Mitova and N. Vassilev, Phosphorus, Sulfur Silicon Relat. Elem., 2013, 188, 1147-1155.

82 G. Keglevich, A. Gruen, I. G. Molnar and I. Greiner, Heteroat. Chem., 2011, 22, 640-648.

83 R. Lenin, R. M. Raju, D. V. N. S. Rao and U. K. Ray, Med. Chem. Res., 2013, 22, 1624-1629.

84 G. Keglevich, A. Grun, S. Garadnay and I. Greiner, Phosphorus, Sulfur Silicon Relat. Elem., 2015, 190, 21162124.

85 L. Widler, K. A. Jaeggi, M. Glatt, K. Mueller, R. Bachmann, M. Bisping, A.-R. Born, R. Cortesi, G. Guiglia, H. Jeker, R. Klein, U. Ramseier, J. Schmid, G. Schreiber, Y. Seltenmeyer and J. R. Green, J. Med. Chem., 2002, 45, 3721-3738.

86 R. Kovacs, A. Gruen, O. Nemeth, S. Garadnay, I. Greiner and G. Keglevich, Heteroat. Chem., 2014, 25, 186-193.

87 S. S. Ratrout, A. e. M. Al Sarabi and K. A. Sweidan, Pharm. Chem. J., 2015, 48, 835-839.

88 S. K. Singh, N. Manne, P. C. Ray and M. Pal, Beilstein J. Org. Chem., 2008, 4(42), DOI: 10.3762/bjoc.4.42.

89 A. Grun, R. Kovacs, S. Garadnay, I. Greiner and G. Keglevich, Lett. Drug Des. Discovery, 2015, 12, 253-258.

90 A. Grun, R. Kovacs, D. I. Nagy, S. Garadnay, I. Greiner and G. Keglevich, Lett. Drug Des. Discovery, 2015, 12, 78-84.

91 D. V. N. S. Rao, R. Dandala, R. Lenin, M. Sivakumaran, S. Shivashankar and A. Naidu, ARKIVOC, 2007, 34-38.

92 M. A. Motaleb, A. S. A. Adli, M. El-Tawoosy, M. H. Sanad and M. Abd Allah, J. Labelled Compd. Radiopharm., 2016, 59, 157-163.

93 M. Lecouvey and Y. Leroux, Heteroat. Chem., 2000, 11, 556561.

94 Actually, the Arbuzov reaction (or Michaelis-Arbuzov reaction) is the reaction of a trialkyl phosphite with an alkyl halide to form a phosphonate. In this case, the reaction takes place with an acyl chloride to give a ketophosphonate.

95 M. Lecouvey, I. Mallard, T. Bailly, R. Burgada and Y. Leroux, Tetrahedron Lett., 2001, 42, 8475-8478.

96 E. Guenin, D. Ledoux, O. Oudar, M. Lecouvey and M. Kraemer, Anticancer Res., 2005, 25, 1139-1145.

97 O. Bortolini, G. Fantin, M. Fogagnolo, S. Rossetti, L. Maiuolo, G. Di Pompo, S. Avnet and D. Granchi, Eur. J. Med. Chem., 2012, 52, 221-229. 
98 S. Kachbi Khelfallah, M. Monteil, J. Deschamp, O. Gager, E. Migianu-Griffoni and M. Lecouvey, Org. Biomol. Chem., 2015, 13, 11382-11392.

99 D. M. Mizrahi, T. Waner and Y. Segall, Phosphorus, Sulfur Silicon Relat. Elem., 2001, 173, 1-25.

100 E. Guenin, M. Monteil, N. Bouchemal, T. Prange and M. Lecouvey, Eur. J. Org. Chem., 2007, 3380-3391.

101 K. R. Bhushan, E. Tanaka and J. V. Frangioni, Angew. Chem., Int. Ed., 2007, 46, 7969-7971.

102 M. Seki, Synthesis, 2012, 44, 1556-1558.

103 P. Vachal, J. J. Hale, Z. Lu, E. C. Streckfuss, S. G. Mills, M. MacCoss, D. H. Yin, K. Algayer, K. Manser, F. Kesisoglou, S. Ghosh and L. L. Alani, J. Med. Chem., 2006, 49, 3060-3063.

104 M. L. Lolli, B. Rolando, P. Tosco, S. Chaurasia, A. Di Stilo, L. Lazzarato, E. Gorassini, R. Ferracini, S. Oliaro-Bosso, R. Fruttero and A. Gasco, Bioorg. Med. Chem., 2010, 18, 2428-2438.

105 M. Egorov, S. Aoun, M. Padrines, F. Redini, D. Heymann, J. Lebreton and M. Mathe-Allainmat, Eur. J. Org. Chem., 2011, 7148-7154.

106 J. B. Rodriguez, Synthesis, 2014, 46, 1129-1142.

107 A. Chiminazzo, L. Sperni, M. Damuzzo, G. Strukul and A. Scarso, ChemCatChem, 2014, 6, 2712-2718.

108 G. Li, M. Wu, F. Liu and J. Jiang, Synthesis, 2015, 47, 37833796.

109 O. Bortolini, I. Mulani, A. De Nino, L. Maiuolo, M. Nardi, B. Russo and S. Avnet, Tetrahedron, 2011, 67, 5635-5641.

110 S. A. Holstein, D. M. Cermak, D. F. Wiemer, K. Lewis and R. J. Hohl, Bioorg. Med. Chem., 1998, 6, 687-694.

111 A. R. P. M. Valentijn, O. van den Berg, G. A. van der Marel, L. H. Cohen and J. H. van Boom, Tetrahedron, 1995, 51, 2099-2108.

112 L. W. Shull and D. F. Wiemer, J. Organomet. Chem., 2005, 690, 2521-2530.

113 M. A. Maalouf, A. J. Wiemer, C. H. Kuder, R. J. Hohl and D. F. Wiemer, Bioorg. Med. Chem., 2007, 15, 1959-1966.

114 J. Beck, S. Gharbi, A. Herteg-Fernea, L. Vercheval, C. Bebrone, P. Lassaux, A. Zervosen and J. Marchand-Brynaert, Eur. J. Org. Chem., 2009, 85-97.

115 Y. Du, K.-Y. Jung and D. F. Wiemer, Tetrahedron Lett., 2002, 43, 8665-8668.

116 M. T. Rubino, M. Agamennone, C. Campestre, P. Campiglia, V. Cremasco, R. Faccio, A. Laghezza, F. Loiodice, D. Maggi, E. Panza, A. Rossello and P. Tortorella, ChemMedChem, 2011, 6, 1258-1268.

117 E. W. J. Petrillo and M. A. Ondetti, Med. Res. Rev., 1982, 2, 141.

118 D. V. Patel, M. G. Young, S. P. Robinson, L. Hunihan, B. J. Dean and E. M. Gordon, J. Med. Chem., 1996, 39, 4197-4210.

119 S. B. Singh, D. L. Zink, J. M. Liesch, M. A. Goetz, R. G. Jenkins, M. Nallin-Omstead, K. C. Silverman, G. F. Bills and R. T. Misley, Tetrahedron, 1993, 49, 5917-5926. 120 R. B. Lingham, K. C. Silverman, G. F. Bills, C. Cascales, M. Sanchez, R. G. Jenkins, S. E. Gartner, I. Martin, M. T. Diez, F. Peláez, S. Mochales, Y.-L. Kong, R. W. Burg,
M. S. Meinz, L. Huang, M. Nallin-Omstead, S. D. Mosser, M. D. Schaber, C. A. Omer, D. L. Pompliano, J. B. Gibbs and S. B. Singh, Appl. Microbiol. Biotechnol., 1993, 40, 370-374.

121 S. B. Singh, Tetrahedron Lett., 1993, 34, 6521-6524.

122 S. B. Singh, H. Jayasuriya, K. C. Silverman, C. A. Bonfiglio, J. M. Williamson and R. B. Lingham, Bioorg. Med. Chem., 2000, 8, 571-580.

123 T. J. Tucker, M. T. Abrams, C. A. Buser, J. P. Davide, M. EllisHutchings, C. Fernandes, J. B. Gibbs, S. L. Graham, G. D. Hartman, H. E. Huber, D. Liu, R. B. Lobell, W. C. Lumma, R. G. Robinson, J. T. Sisko and A. M. Smith, Bioorg. Med. Chem. Lett., 2002, 12, 2027-2030. 124 J. M. Bergman, M. T. Abrams, J. P. Davide, I. B. Greenberg, R. G. Robinson, C. A. Buser, H. E. Huber, K. S. Koblan, N. E. Kohl, R. B. Lobell, S. L. Graham, G. D. Hartman, T. M. Williams and C. J. Dinsmore, Bioorg. Med. Chem. Lett., 2001, 11, 1411-1415.

125 F. P. Coxon, M. H. Helfrich, B. Larijani, M. Muzylak, J. E. Dunford, D. Marshall, A. D. McKinnon, S. A. Nesbitt, M. A. Horton, M. C. Seabra, F. H. Ebetino and M. J. Rogers, J. Biol. Chem., 2001, 276, 48213-48222.

126 Y.-L. Liu, R. Cao, Y. Wang and E. Oldfield, ACS Med. Chem. Lett., 2015, 6, 349-354.

127 K. W. Cheng, J. P. Lahad, J. W. Gray and G. B. Mills, Cancer Res., 2005, 65, 2516-2519.

128 A. J. Roelofs, P. A. Hulley, A. Meijer, F. H. Ebetino, R. G. G. Russell and C. M. Shipman, Int. J. Cancer, 2006, 119, 1254-1261.

129 C. E. McKenna, B. A. Kashemirov, K. M. Blazewska, I. Mallard-Favier, C. A. Stewart, J. Rojas, M. W. Lundy, F. H. Ebetino, R. A. Baron, J. E. Dunford, M. L. Kirsten, M. C. Seabra, J. L. Bala, M. S. Marma, M. J. Rogers and F. P. Coxon, J. Med. Chem., 2010, 53, 3454-3464.

130 K. M. Blazewska, F. Ni, R. Haiges, B. A. Kashemirov, F. P. Coxon, C. A. Stewart, R. Baron, M. J. Rogers, M. C. Seabra, F. H. Ebetino and C. E. McKenna, Eur. J. Med. Chem., 2011, 46, 4820-4826.

131 B. Fiszer and J. Michalski, Rocz. Chem., 1954, 28, 185-195.

132 K. Lee and D. F. Wierner, Phosphorus, Sulfur Silicon Relat. Elem., 1993, 75, 87-90.

133 M. Ferella, Z.-H. Li, B. Andersson and R. Docampo, Exp. Parasitol., 2008, 119, 308-312.

134 P. Coutrot and G. A., Synthesis, 1986, 661-664.

135 K. Hackeloer, G. Schnakenburg and S. R. Waldvogel, Eur. J. Org. Chem., 2011, 6314-6319.

136 L. Albrecht, B. Richter, H. Krawczyk and K. A. Jorgensen, J. Org. Chem., 2008, 73, 8337-8343.

137 F. P. Coxon, L. Joachimiak, A. K. Najumudeen, G. Breen, J. Gmach, C. Oetken-Lindholm, R. Way, J. E. Dunford, D. Abankwa and K. M. Blazewska, Eur. J. Med. Chem., 2014, 84, 77-89.

138 Y. Mu, R. A. Gibbs, L. M. Eubanks and C. D. Poulter, J. Org. Chem., 1996, 61, 8010-8015.

139 R. A. Gibbs, U. Krishnan, J. M. Dolence and C. D. Poulter, J. Org. Chem., 1995, 60, 7821-7829.

140 Y. Shao, J. T. Eummer and R. A. Gibbs, Org. Lett., 1999, 1, 627-630. 
141 T. J. Zahn, C. Weinbaum and R. A. Gibbs, Bioorg. Med. Chem. Lett., 2000, 10, 1763-1766.

142 R. M. Phan and C. D. Poulter, J. Org. Chem., 2001, 66, 67056710.

143 J. Liu, W. Liu, H. Ge, J. Gao, Q. He, L. Su, J. Xu, L.-q. Gu, Z.-s. Huang and D. Li, Biochim. Biophys. Acta, Gen. Subj., 2014, 1840, 1051-1062.
144 A. L. Marzinzik, R. Amstutz, G. Bold, E. Bourgier, S. Cotesta, J. F. Glickman, M. Goette, C. Henry, S. Lehmann, J. C. D. Hartwieg, S. Ofner, X. Pelle, T. P. Roddy, J.-M. Rondeau, F. Stauffer, S. J. Stout, A. Widmer, J. Zimmermann, T. Zoller and W. Jahnke, ChemMedChem, 2015, 10, 1884-1891. 